\title{
Molecular Characterization of Organosulfates in Arctic Ocean and Antarctic atmospheric aerosols
}

\author{
Yuqing $\mathrm{Ye}^{1}$, Zhouqing Xie ${ }^{1,2^{*}}$, Ming Zhu ${ }^{3}$, Xinming Wang ${ }^{3}$
}

${ }^{1}$ Institute of Polar Environment \& Anhui Key Laboratory of Polar Environment and Global Change, School of Earth and Space Sciences, University of Science and Technology of China, Hefei 230026, China

${ }^{2}$ Center for Excellence in Urban Atmospheric Environment, Institute of Urban Environment, Chinese Academy of Sciences, Xiamen, Fujian 361021, China.

$10{ }^{3}$ State Key Laboratory of Organic Geochemistry and Guangdong Key Laboratory of Environmental Protection and Resources Utilization, Guangzhou, 510640, China

Correspondence to: Zhouqing Xie (zqxie@ustc.edu.cn)

Abstract. Organic aerosols are ubiquitous components of atmospheric aerosols. Organosulfate aerosols have been detected

15 in the Arctic Ocean atmosphere and may play an important role in the radiative balance in Polar Regions. Aerosol samples from the Arctic Ocean and Antarctic atmosphere during 2014/2015 CHINARE were analysed by ultrahigh resolution mass spectrometry coupled with negative ion mode electrospray ionization (ESI(-)-UHRMS). Hundreds of organic compounds were detected and tentatively determined by their formulas, including organosulfates (OSs), nitrooxy-organosulfates (NOSs), organonitrates (ONs) and oxygenated hydrocarbons (OxyCs). The number of OSs/NOSs accounted for 28-32\% of the total number of detected molecules at polar sites and ONs were 28-40\%. Organic compounds of Arctic Ocean and Antarctic aerosols had high oxidation states for carbon and a large percentage of high molecular weight formulas; this indicated that "aged" organic aerosols likely comprise a significant part of the polar atmosphere. We hypothesized that highly oxidized HMW compounds tend to be transported to the polar area from stratospheric reservoirs. Dramatic differences of the molecular characteristics were observed when we compared aerosol samples between polar sites and Guangzhou sites, reflecting the different oxidation mechanisms and atmospheric transmission. The polar sites contained higher fractions of OSs/NOSs and lower fractions of ONs than the Guangzhou sites did; this indicated that the oxidation of $\mathrm{NO}_{\mathrm{x}}$ was weaker in the polar region. Observing that the fraction and oxidation states of polycyclic aromatic OSs/NOSs polar regions were similar to the Guangzhou urban area but not the rural area implied an anthropogenic influence on OSs/NOSs in remote polar areas. In addition, the contribution of potential precursors (anthropogenic and biogenic volatile organic compounds) to OS and NOS formation as well as the effects of nss- $\mathrm{SO}_{4}$ aerosols, $\mathrm{pH}$ and $\mathrm{RH}$ on OS formation in polar areas were discussed. 
Atmos. Chem. Phys. Discuss., https://doi.org/10.5194/acp-2019-410

Atmospheric

Manuscript under review for journal Atmos. Chem. Phys.

Chemistry

Discussion started: 6 May 2019

(c) Author(s) 2019. CC BY 4.0 License.

and Physics

Discussions

(c) (i)

Our study presents the first overview of OSs and ONs in the Arctic Ocean and Antarctic atmosphere and promotes the understanding of their characteristics and sources.

\section{Introduction}

Atmospheric aerosols directly affect radiation by absorbing and scattering radiation (Brimblecombe, 1996; Seinfeld et al.,

5 1998; Jacobson et al., 2000). They also serve as cloud condensation nuclei (CCN) and provide indirect radiation forcing (Seinfeld et al., 1998; Novakov and Penner, 1993). Exposure to aerosols causes respiratory and cardiovascular disease which increases mortality rates (Elder and Oberdörster, 2006; Pope Iii et al., 2002; Hallquist et al., 2009). Hence, aerosols play a key role in climate change, air quality and have an adverse effect on human health.

Organic aerosols (OAs) comprise 20-90\% of the submicron atmospheric particulate mass (Kroll and Seinfeld, 2008;

10 Hallquist et al., 2009; Jimenez et al., 2009). The complexity of OAs inhibits our understanding, as only 10-30\% of OAs have thus far been identified (Hoffmann et al., 2011). Secondary organic aerosols (SOAs) are a substantial component of OAs. Researches have been verified SOAs are ubiquitous in the Arctic and Antarctic atmosphere, and biogenic volatile organic compounds (BVOCs) are important precursors of SOA, such as isoprene, $\alpha$-pinene, monoterpene and sesquiterpene; these BVOCs-derived SOA can used as tracers and their contribution to total organic carbon (OC) varied from $0.01-56 \mathrm{ng}^{-3}$

15 (Kawamura et al., 1996; Fu et al., 2009; Fu et al., 2013; Hu et al., 2013). They are formed though photooxidation, heterogeneous and multiphase processes of organic matter in the atmosphere, as well as participate in multiple reactions (Ravishankara, 1997; Goldstein and Galbally, 2007; Kroll and Seinfeld, 2008; Jimenez et al., 2009).

Organosulfate (OS) aerosols, as a newly-identified but important class of SOA, contribute $\sim 4-30 \%$ of ambient submicron OAs in a variety of field studies, ranging from Arctic, marine, forest, rural to urban areas (Surratt et al., 2008; Lukács et al.,

20 2009; Hawkins et al., 2010; Stone et al., 2012; Tolocka and Turpin, 2012; Hansen et al., 2014; Frossard et al., 2011) and can act as tracers of SOA information (Zhang and Worton, 2012; Nozière et al., 2010; Nozière et al., 2015; Hettiyadura et al., 2018). Because OS molecules contain both hydrophilic and hydrophobic functional groups and relates to the optical properties of aerosols, it changes the potential impact on climate by affecting the aerosol hygroscopicity (Pang et al., 2006) and light absorption (Song et al., 2013; Jacobson, 1999; Lu et al., 2011; Laskin et al., 2015).

Formation mechanisms and molecular-level characterization of OSs need further investigation to improve our knowledge of OA sources, evolution and properties. Many studies have shown that biogenic volatile organic compounds (BVOCs) such as isoprene, monoterpenes, sesquiterpenes, oxygenated derivatives and some green leaf alcohols play an important role in producing OSs (Surratt et al., 2007; Iinuma et al., 2007; Surratt et al., 2008; N. L. Ng, 2008; Riva et al., 2016a; Zhang and Worton, 2012; Mael et al., 2015; Schindelka et al., 2013; Shalamzari et al., 2014; Shalamzari et al., 2016; Liggio and Li,

30 2006; Iinuma et al., 2009; Perri et al., 2010; Chan et al., 2011; Darer et al., 2011; Chen and Jang, 2012; Barbosa et al., 2017; Szmigielski, 2016; Nozière et al., 2010; McNeill et al., 2012). However, recent studies have focused on anthropogenic emissions (e.g. alkanes, polycyclic aromatic hydrocarbons (PAHs), unsaturated fatty acids and diesel fuel) as OS precursors 
Atmos. Chem. Phys. Discuss., https://doi.org/10.5194/acp-2019-410

Manuscript under review for journal Atmos. Chem. Phys.

to try and explain a large number of unidentified OSs with aliphatic or aromatic carbon skeletons; their results showed the human effect on OS formation is underestimated and potentially enormous (Tao et al., 2014; Wang et al., 2016; Kuang et al., 2016; Riva et al., 2015; Riva et al., 2016c; Passananti et al., 2016; Shang et al., 2016; Blair et al., 2017). These organic precursors are further oxidized and react with sulfur-containing nucleophiles $-\mathrm{SO}_{2} / \mathrm{SO}_{3}$ gas, dimethyl sulfide, sulfate acids

5 and $\mathrm{SO}_{3} / \mathrm{SO}_{4}$ radicals - involving heterogeneous and multiphase reactions.

The polar environment is well known to be sensitive to perturbations of the radiative budget. The Arctic and the Antarctic are warming at a rate of twice the global average with the atmospheric temperature increasing by $2 \sim 3{ }^{\circ} \mathrm{C}$ (ACIA, 2004; IPCC, 2013; Bromwich et al., 2012; Cohen et al., 2012). Atmospheric aerosols are pivotal factors changing the polar radiative balance. Since Mitchell first observed an Arctic haze in 1956 (Mitchell, 1957), concerns about polar atmospheric aerosols

10 and the influence of humans has increased. These polar aerosols primarily consist of sulfate and organic aerosols and indicate their anthropogenic sources (Minikin et al., 1998; Mazzera et al., 2001; Mishra et al., 2004; Quinn et al., 2007; Tunved et al., 2013; Nguyen et al., 2016). Frossard et al. analysed the composition of Arctic organic aerosols during a haze period and detected organic sulfate functional groups in aerosol samples using FTIR spectroscopy (Frossard et al., 2011). Hansen et al. examined the speciation of secondary organic aerosols using HPLC with a quadrupole Time-of-Flight mass

15 spectrometer and reported the occurrence of 12 organosulfates and one nitrooxy organosulfate in Arctic aerosols at Zeppelin Mountain and Station Nord, contributing 7 20\% of the total organic aerosols (Hansen et al., 2014). However, the investigation of OS aerosols in the polar region is still rare.

This study presents the molecular characteristics of organosulfates (OSs), nitrooxy organosulfates (NOSs), organonitrates (ONs) and certain oxygenated hydrocarbons (OxyCs) found in aerosol samples collected in the Arctic and Antarctic during

20 the 2014/2015 Chinese National Arctic/Antarctic Research Expedition (CHINARE). We utilized an Orbitrap mass spectrometer with high mass resolution and accuracy as well as electrospray ionization (ESI) as a soft ionization source in the negative ion mode. The differences in the molecular levels, oxidation state and aromaticity among the detected aerosols of Arctic, Antarctic and Guangzhou sites were discussed.

\section{Experimental}

\section{2.1 Sample Collection}

For the polar samples, total suspended particles (TSP) samples as well as field blank samples were collected aboard the CHINARE 14 cruise from the East China Sea $\left(35^{\circ} \mathrm{N}, 130^{\circ} \mathrm{E}\right)$ to the Arctic Ocean $\left(81^{\circ} \mathrm{N}, 157^{\circ} \mathrm{W}\right)$ from July 2014 to September 2014. TSP samples were also collected at Zhongshan Station $\left(70^{\circ} \mathrm{S}, 76^{\circ} \mathrm{E}\right)$ and $\mathrm{Kunlun}$ Station $\left(80^{\circ} \mathrm{S}, 77^{\circ} \mathrm{E}\right)$ in Antarctica from January to February 2015. In the expedition cruise to the Arctic Ocean, TPS samples were collected by a 30 high-volume air sampler on the uppermost front deck of the icebreaker Xuelong with a sampling flow rate of $1.05 \mathrm{~m}^{3} \mathrm{~min}^{-1}$ through a quartz fibre filter (QFF) (Whatman QM-A, 20.3×25.4 cm, UK). The high-volume air sampler was placed windward to reduce the impact of ship exhaust. Each sampling lasted for a day and the air volume ranged from 1360 to 1514 
Atmos. Chem. Phys. Discuss., https://doi.org/10.5194/acp-2019-410

Manuscript under review for journal Atmos. Chem. Phys.

$\mathrm{m}^{3}$ (at $0{ }^{\circ} \mathrm{C}$ and $1 \mathrm{~atm}$ ). In Antarctica, medium-volume air samplers were placed at the two stations to collect TSP samples through 82-mm QFFs. Each sampling lasted for $12-24 \mathrm{~h}$ and the air volume ranged from 52.6 to $105.1 \mathrm{~m}^{3}$ (at $0{ }^{\circ} \mathrm{C}$ and 1 atm). The QFFs were prebaked at $450{ }^{\circ} \mathrm{C}$ for $4 \mathrm{~h}$ to remove potential organic contamination. QFFs were then wrapped with aluminium foil, zipped in plastic bags and stored in freezers at $-20{ }^{\circ} \mathrm{C}$ before further analysis.

For the Guangzhou samples, 24-hours filter-based PM2.5 samples were collected in an urban site $\left(23^{\circ} \mathrm{N}, 113^{\circ} \mathrm{E}\right)$ and a rural site $\left(22^{\circ} \mathrm{N}, 113^{\circ} \mathrm{E}\right)$ using a high-volume air sampler (Tisch Environmental, Inc. Ohio, USA) with a constant flow rate of $1.1 \mathrm{~m}^{3} \mathrm{~min}^{-1}$. The procedures for prebaking the filters (Whatman QM-A, 20.3×25.4 cm, UK) and preserving samples were identical with the polar samples.

\subsection{Sample Analysis}

\section{$10 \quad$ 2.2.1 ESI-UHRMS Analysis}

Considering the low concentrations of Arctic and Antarctic atmospheric aerosols, two Arctic samples and four Antarctic samples from the same location were combined for pre-processing and analysis. Portions of the filters $\left(\sim 25 \mathrm{~cm}^{2}\right.$, representing approximately $68 \mathrm{~m}^{3}$ and $36 \mathrm{~m}^{3}$ of sampled air in the Arctic and the Antarctic, respectively) were extracted with $10 \mathrm{~mL}$ of a 1:1 v:v mixture of methanol and MQ water in an ultrasonic bath for $1 \mathrm{~h}$. The extract was then filtered with a glass springe equipped with a $0.25 \mu \mathrm{m}$ PTFE membrane to remove insoluble materials. These extraction and filtration steps were performed twice; the extracts were combined and evaporated to dryness under a gentle $\mathrm{N}_{2}$ steam. The extracts were immediately redissolved in $400 \mu \mathrm{L}$ of 1:1 v:v mixture of MQ water and acetonitrile.

Sample aliquots $(70 \mu \mathrm{L})$ of the extracts were directly injected by an autosampler and travelled through a steel capillary column for $3 \mathrm{~min}$. In this study, we chose direct injection rather than liquid chromatography (LC) injection because our

20 objective was to obtain an overall picture of the molecular characteristics of OS/NOS aerosols from the Polar Regions. The extracts from the polar samples were analysed using an LTQ-Orbitrap XL mass spectrometer (Thermo Fisher Scientific, USA) coupled with a heated ESI source, with the spray voltage set at $3 \mathrm{kV}$. The system was operated under negative ESI mode with a resolving power of 100,000 at m/z 400 and absolute mass error $<0.02 \mathrm{ppm}$; and signals of 50-800 m/z range were recorded for data processing. The extracts from the Guangzhou samples (one sample from urban site, one sample from rural site) were analysed using a solariX XR FT-ICR MS (Bruker Daltonik GmbH, Bremen, Germany) (equipped with a 9.4 $\mathrm{T}$ refrigerated actively shielded superconducting magnet (Bruker Biospin, Wissembourg, France) and the Paracell analyzer cell) in $3 \mathrm{kV}$ negative ESI mode. A mass-resolving power $>450,000$ at $\mathrm{m} / \mathrm{z} 319$ with absolute mass error $<0.02 \mathrm{ppm}$ was achieved; signals of 150-1000 m/z range were recorded. The same pre-treatments were applied for field blank samples.

\subsubsection{Inorganic Ion Analysis}

Soluble inorganic ions were analysed by ion chromatography (Dionex DX-120, Osaka, Japan). A round, 1-inch diameter filter was cut off to rinse with $10 \mathrm{~mL}$ of MQ water in an ultrasonic bath for $\sim 40 \mathrm{~min}$. After centrifuging for $10 \mathrm{~min}$, the 
Atmos. Chem. Phys. Discuss., https://doi.org/10.5194/acp-2019-410

Manuscript under review for journal Atmos. Chem. Phys.

Chemistry

Discussion started: 6 May 2019

(c) Author(s) 2019. CC BY 4.0 License.

supernatant was extracted and the remained filter was treated again following the same procedure. The extracts were combined and filtered through a $0.25 \mu \mathrm{m}$ PTFE membrane before injection into the IC system. The cations were analysed using a CS12A analytical column with a CDRS600 guard column. Anions were analysed using an AS19 analytical column with a CDRS500 guard column.

\section{$5 \quad$ 2.3 Data Processing}

The mass spectra from Orbitrap MS were obtained and analysed by Xcalibur software (V2.1, Thermo Fisher Scientific, USA) and the mass spectra from FT-ICR MS were initially retrieved in DataAnalysis software (V4.4, Bruker Daltonics). All ions within the $50-800 \mathrm{~m} / \mathrm{z}$ range (Orbitrap MS) or 150-1000 m/z range (FT-ICR MS) with a signal-to-noise ratios (s/n) $\geq$ 10 were selected to elucidate possible formulas with mass tolerances of $\pm 2 \mathrm{ppm}$. These formulas are expressed as

$10 \mathrm{C}_{c} \mathrm{H}_{h} \mathrm{O}_{o} \mathrm{~N}_{n} \mathrm{~S}_{s}$ with the constraints of 1-80 of $c, 2-200$ of $h, 0-50$ of $o, 0-5$ of $n$ and 0-2 of $s$. Further limitations were applied to ensure the retrieved compounds did exist in nature: $\mathrm{H} / \mathrm{C}, \mathrm{O} / \mathrm{C} / \mathrm{N} / \mathrm{C}, \mathrm{S} / \mathrm{C}$ and double bond equivalent to carbon number ratios $(\mathrm{DBE} / \mathrm{C})$ were restricted in the range of $0.3-30,0-3,0-0.5,0-0.2$ and $0-1$, respectively; the formulas which broke the nitrogen rule for even electron ions were excluded. Compounds with carbon, nitrogen and sulfur numbers satisfying $4 s+3 n \leq$ $o$ were tentatively regarded as organosulfates, organonitrates and nitrooy organosulfates. The raw data of blank filters were

15 processed the same way and the formulas exported from blank filters were subtracted from sample-derived formulas, regardless of the intensity (Lin et al., 2012a; Lin et al., 2012b).

The DBE value (calculated using Eq. 1) provides the degree of molecular unsaturation without inclusion of the double bonds from sulfate groups ( $2 \mathrm{~S}=\mathrm{O})$ (Wang et al., 2016).

$\mathrm{DBE}=\frac{2 c+2+n-h}{2}$

20 The aromaticity equivalent (Xc) identified potential monocyclic and polycyclic aromatic compounds (Yassine et al., 2014; Tong et al., 2016; Wang et al., 2017b). A general equation for Xc containing only carbon, hydrogen, nitrogen, sulfur and phosphorus is given in Eq. (2):

$X c=\frac{3[D B E-(m \times o+n \times s)]-2}{D B E-(m \times o+n \times s)}$

where $o$, and $s$ refer to the number of oxygen and sulfur atoms, respectively while $m$, and $n$ correspond to the fraction of oxygen and sulfur involved in the $\pi$-bond structure of the compound. If $\mathrm{DBE} \leq(m \times o+n \times s)$, then Xc $=0$. In this study, $m=n=0.5$ was used for the assigned formulas since they were detected in negative ESI mode as ESI ${ }^{-}$is sensitive to carboxylic groups and carboxylic acids are characterized as $m=n=0.5$. If either $o$ or $n$ is an odd number, $(m \times o+n \times s)$ is rounded to the next lower integer. A value of $\mathrm{Xc} \geq 2.5000$ was proposed as unambiguous minimum criteria for the presence of an aromatic structure; $\mathrm{Xc} \geq 2.7143,2.8000,2.8333,2.9231$ were considered as the thresholds for molecules containing 30 cores of naphthalene, anthracene, pyrene and ovalene, respectively.

Carbon oxidation state (OSc) has been used as a metric for the degree of oxidation of atmospheric organic aerosols (Kroll et al., 2011). For organic compounds consisting of carbon, hydrogen and oxygen, OSc can be calculated using Eq. (3): 
Atmos. Chem. Phys. Discuss., https://doi.org/10.5194/acp-2019-410

Manuscript under review for journal Atmos. Chem. Phys.

Discussion started: 6 May 2019

(c) Author(s) 2019. CC BY 4.0 License.

(c) (i)

Atmospheric

Chemistry

and Physics

Discussions

OSc $\approx 20 / \mathrm{C}-\mathrm{H} / \mathrm{C}$

Where $\mathrm{O} / \mathrm{C}$ and $\mathrm{H} / \mathrm{C}$ are the elemental ratios of oxygen-to-carbon and hydrogen-to-carbon. Eq. (3) can be applied to organosulfates and organonitrates because most of the ESI-MS detected heteroatom-containing compounds have only minor deviations in their oxidation states.

In this study, OS, NOS, ON and OxyC refer to organosulfate, nitrooy-organosulfate, organonitrate and oxygenated hydroxycarbon.

\subsection{Back-trajectory calculations}

Back-trajectories for Arctic Centre Sea $\left(81.05^{\circ} \mathrm{N}, 157.4^{\circ} \mathrm{W}\right)$, Arctic Pack Ice $\left(71.5^{\circ} \mathrm{N}, 168.05^{\circ} \mathrm{W}\right)$, Antarctic Kunlun Station (80.42 $\left.{ }^{\circ} \mathrm{S}, 77.12^{\circ} \mathrm{E}\right)$ and Antarctic Zhongshan Station (70.13 $\left.{ }^{\circ} \mathrm{S}, 76.58^{\circ} \mathrm{E}\right)$ were computed using the Hybrid Single

10 Particle Lagrangian Integrated Trajectory (HYSPLIT) model from the NOAA Air Resources Laboratory (Draxler and Rolph, 2003). BTs were back-traced for $120 \mathrm{~h}$ with $6 \mathrm{~h}$ steps at elevations of 100, 500 and $1000 \mathrm{~m}$ above ground level.

\subsection{Aerosol pH calculation}

A thermodynamic equilibrium model (ISORROPIA II) were used to predict the $\mathrm{pH}$ of the polar aerosol samples for the $\mathrm{K}^{+}-\mathrm{Ca}^{2+}-\mathrm{Mg}^{2+}-\mathrm{NH}_{4}{ }^{+}-\mathrm{Na}^{+}-\mathrm{SO}_{4}{ }^{2-}-\mathrm{NO}_{3}{ }^{-}-\mathrm{Cl}^{-}-\mathrm{H}_{2} \mathrm{O}$ system (Fountoukis and Nenes, 2007). The model was set up in the

15 forward mode with a metastable state. The concentrations of inorganic ions, the relative humidity and temperature were input into the model together to calculate the $\mathrm{pH}$ of aerosol bulk.

\section{Results and Discussion}

\subsection{General Characterizations}

The main purpose of this study was to tentatively identify organosulfate and other organic aerosols in the polar 20 atmosphere and compare them with those of Guangzhou, whose atmosphere is affected by anthropogenic pollution, plant emissions and ocean aerosols.

Using HR-MS (Orbitrap for Arctic and Antarctic, FT-ICP for Guangzhou) equipped with an ESI- mode, assigned formulas of organic aerosols were detected in Arctic Centre Sea, Arctic Pack Ice, Antarctic Kunlun Station, Antarctic Zhongshan Station, Rural and Urban Guangzhou; these formulas were classified into four groups by their elemental

25 composition: oxygenated hydrocarbons ( $\mathrm{CHO})$, organosulfate (CHOS), organonitrate (CHON) and nitrooxy-organosulfate (CHONS). In total, there were 330, 215 and 1777 (1069 in common) different OS and ON molecular formulas found in atmospheric particles from the Arctic, Antarctic and Guangzhou, respectively.

Table 1 summarizes the elemental formulas obtained from the six sampling sites, including the numbers and the fractional percentages of the identified formulas, carbon number range, average molecular weight values (intensity-weighted average \pm 30 standard deviation), DBE, O/C and OSc, and the numbers of aliphatic and aromatic compounds. Among the six sites, 
Atmos. Chem. Phys. Discuss., https://doi.org/10.5194/acp-2019-410

Manuscript under review for journal Atmos. Chem. Phys.

Chemistry

Discussion started: 6 May 2019

(c) Author(s) 2019. CC BY 4.0 License.

and Physics

Discussions

(c) (i)

approximately 21-32\% of formulas were OSs and NOSs (i.e. CHOS (blue) and CHONS (light blue) in Fig. 1). Obviously, samples collected in Guangzhou had the greatest number of total formulas (2270 in urban areas, 1918 in the rural areas) as well as formulas in each category, far more than the polar areas (25 in the Arctic Center Sea, 487 in the Arctic Pack ice, 124 in the Antarctic Kunlun Station and 247 in the Zhongshan Station). The Arctic Centre Sea was at the highest latitude

$5\left(81.07^{\circ} \mathrm{N}\right)$; the fewest number of formulas were found there, just $1 \%$ of the number of formulas found in Guangzhou aerosols. However, OSs and NOSs in the polar areas accounted for a larger fraction (up to $~ 30 \%$ ) of the total assigned formulas than those from Guangzhou ( $20 \%$, see Table 1 and Fig. 1 pie charts). But Guangzhou had the most abundant ON components among the three regions, accounting for nearly $50 \%$ of the total formulas; while ONs in Arctic and Antarctic aerosols accounted for $\sim 30 \%$. Because Arctic and Antarctic samples were collected during the summertime at each location, there

10 was no nocturnal oxidation of $\mathrm{NO}_{3}$ taking place. This may partially explain the smaller ON fractions in the polar atmosphere relative to Guangzhou samples. In addition, the Guangzhou $\mathrm{NO}_{\mathrm{x}}$ concentrations far exceeded those in the Polar Regions (Shao et al., 2009; Seppälä et al., 2007). It should be noted that in the same polar area, higher-latitude sites (i.e. Arctic Center Sea and Antarctic Kunlun Station) had fewer aerosol formula types than the lower-latitude sites (i.e. Arctic Pack Ice and Zhongshan Station). One possible reason for this observation stems from the effect other continents have on lower latitude

15 sites, with additional pollutants from natural and anthropogenic sources, as shown in the backward trajectories from sampling sites in Fig. S1.

Mass spectra of compounds detected by Orbitrap with ESI- were reconstructed as seen in Fig. 1, displaying the assigned formulas by setting the most abundant peak (CHO, CHON, CHOS and CHONS) as 100\%. Considering the different signal responses from various species, we did not discuss the absolute abundance in this study. The total identified formulas

20 covered a wide range of molecular weights (90-800 Da) among the six sites. Polar atmospheric aerosol compounds displayed more dispersive molecular weight ranges, composed mostly of MWs from 250-500 Da; MW ranges from Guangzhou samples were from 200-400 Da (Fig. 2). Moreover, half of the OSs and NOSs in polar aerosols had MW values between 400-600 Da as compared to Guangzhou values of 300-400 Da. The highest peaks in the mass spectra varied among different sites - the peaks centred 100-200 Da in samples from the Arctic Pack Ice zone and Antarctic Zhongshan Station;

25 peaks from Guangzhou samples were centred from 250-400 Da. There was no clear distribution in samples from the Arctic Centre Sea zone and Antarctic Kunlun Station due to the relatively few number of formulas detected. These discrepancies in MW distributions between polar sites and Guangzhou sites showed a larger fraction of high-molecular-weight (HMW) compounds in the Arctic and Antarctic areas which are possibly due to the preservation of HMW molecules in the stratosphere and subsequent transportation to remote areas instead of reacting with atmospheric oxidants (as LMW

30 molecules tend to do), underlying that aerosols in polar regions and the Guangzhou area undergo different transportation and formation mechanisms. Within a particular sampling site, the OSs and NOSs shows a much higher molecular weight distribution than $\mathrm{ONs}$, partly due to an increase in nitrogen and sulfur atoms which require additional $\mathrm{C}$ and $\mathrm{O}$ atoms. 
Atmos. Chem. Phys. Discuss., https://doi.org/10.5194/acp-2019-410

Manuscript under review for journal Atmos. Chem. Phys.

Discussion started: 6 May 2019

(c) Author(s) 2019. CC BY 4.0 License.

\subsection{Aromaticity and Oxidation state}

Aliphatic compounds, with formulas (DBE-n) $<4$, made up 20\%-30\% of compounds found in Arctic and Antarctic sites, but $>40 \%$ at Guangzhou sites. Xc $\geq 2.5$ was used for confirmation of aromatics in this study (Wang et al., 2017a) and aromatic compounds accounted for a large number of formulas $(>40 \%)$ at these sampling sites. OSs and NOSs displayed an enormous difference in compositions between polar sites and Guangzhou sites (Fig. S2); Figure S2 shows the fractions of aliphatic and aromatic compounds at each sampling site. Nearly $80 \%$ of total OS and NOS molecules were aliphatic and less than $10 \%$ were aromatic with a DBE average of 2.2 in the Guangzhou samples. This was consistent with previous urban area studies (Kuang et al., 2016; Wang et al., 2016; Wang et al., 2017a; Stone et al., 2012; Ma et al., 2014). Compared to the polar regions in this study, aliphatic molecules comprised $0 \%, 32 \%, 19 \%$ and $41 \%$ and aromatic molecules comprised 29\%,

$1039 \%, 24 \%$ and 30\% of all total detected OSs and NOSs at the Arctic Centre Sea, Arctic Pack Ice, Antarctic Kunlun Station and Antarctic Zhongshan Station, respectively. As stressed in previous chamber studies of PAH-derived OSs (Riva et al., 2015), the greater percentage of aromatic OSs and NOSs in the Polar Regions relative to Guangzhou sites suggested that anthropogenic sources contributed more significantly to OS aerosols than the biogenic sources in the Polar Regions.

Van Krevelen (VK) diagrams are usually employed to describe the compositional characteristics of complex organic

15 mixtures, providing the overall oxidation and unsaturation conditions. The $\mathrm{H} / \mathrm{C}$ ratio of each compound found in the MS is plotted versus its O/C ratio, color-coded by Xc value (Wu et al., 2004; Kim et al., 2003), as shown in Fig. 3 (OSs and NOSs), Fig. S3 (ONs) and Fig. S4 (OxyCs). It should be stressed that we used $(o-2 n-3 s) / c$ to replace $o / c$ here, due to nitrate and sulfate groups containing more oxygen atoms than common oxygen-containing functional groups (Wang et al., 2016). Figure 4, Figure S5 and Figure S6 present the OSc as a function of carbon number and color-coded by Xc value of OSs and NOSs, ONs, and OxyCs. Detected OS and NOS compounds in the polar regions and the Guangzhou sites showed clearly different VK diagram patterns and oxidation state diagrams. The majority of OSs and NOSs plotted in 0 to 1.0 of O/C and between ($1)-(+2)$ of OSc for polar samples, while the Guangzhou samples mainly plotted in 0 to 0.8 of $\mathrm{O} / \mathrm{C}$ values and between $(-2)-$ $(+1)$ of OSc values. In Fig.3 and Fig. 4, organosulfate compounds in the light green oval all featured low O/C $(0-(+0.3))$, low $\mathrm{H} / \mathrm{C}(0-(+1.0))$ and high OSc $((-1)-(+1))$ with $\geq 20$ carbon number and were considered as polycyclic aromatic OSs; they were all present at all four polar sites and urban Guangzhou site but absent from rural Guangzhou site (where the biogenic influences dominated). The similarity of polycyclic aromatic OSs in high oxidation states between the polar sites and the Guangzhou urban sites were consistent with previously reported PAH-derived OSs (Staudt et al., 2014; Riva et al., 2015) and suggested that the polar regions were more affected by long-transported or in-situ pollutants from human activities. Nevertheless, OS and NOS molecules plotted in the dark green oval in the VK diagrams and the OSc plots were unique to polar sites, except the Arctic Centre Sea site. These aliphatic OSs and NOSs with 10-20 carbons had O/C ratios of 0.8-1.0 and OSc of 1-2. The high oxidation state indicated that there were more "aged" oxidized organic aerosols in the polar atmosphere, partly due to the longer resistant time of aerosols and more light exposure in the summertime polar atmosphere. This corresponds to the inference from high concentration of HMW molecules in polar sites as mentioned above. Previous 
Atmos. Chem. Phys. Discuss., https://doi.org/10.5194/acp-2019-410

Manuscript under review for journal Atmos. Chem. Phys.

Chemistry

Discussion started: 6 May 2019

(c) Author(s) 2019. CC BY 4.0 License.

$\frac{\text { and Physics }}{\text { Discussions }}$

(c) (i)

studies have observed that photochemical activity is promoted in the polar atmosphere where oxygenated organic aerosols are a mix of primary marine aerosols and transported SOA from other continents (Mochida et al., 2002; Hawkins et al., 2010; Russell et al., 2010).

The aromaticity and oxidation states of ONs and OxyCs were quite different than OSs. Comparing the three species

5 (OxyCs, ONs, OSs and NOSs) measured at a single Polar Region site, OxyCs had the largest percentage of aromatic molecules and the smallest percentage of aliphatic molecules, yet ONs contained the most abundant aliphatic components (Fig. S6).

\subsection{Potential Precursors and Atmospheric Implications}

Biogenic VOCs (BVOCs), such as isoprene, $\alpha$-pinene, $\beta$-pinene and limonene, as well as anthropogenic VOCs (AVOCs)

10 are important precursors of organosulfate aerosols according to previous laboratory and field studies (Surratt et al., 2007; Surratt et al., 2008; Chan et al., 2011; Staudt et al., 2014; Riva et al., 2015; Riva et al., 2016c; Meade et al., 2016; Riva et al., 2016b; Barbara Nozière, 2010; Shang et al., 2016; Olson et al., 2011; Zhang and Worton, 2012; Szmigielski, 2016; Lin et al., 2013). These published organosulfates whose precursors have been verified, were used as "standard" organosulfates to estimate potential precursors of detected OSs and NOSs in the polar atmosphere. Assigned OSs with identical carbon,

15 hydrogen, nitrogen and sulfur atoms but more oxygen atoms than "standard" OSs were temporarily considered to have the same precursors because organic aerosols in polar regions have high oxidation states. By comparing their formulas, the OSs and NOSs were classified as AVOC-derived, BVOC-derived, AVOC/BVOC-derived and unknown-precursor organosulfates (Fig. 5). In the Arctic Centre Sea, none of seven OSs matched the "standard" OSs. However, they were more likely generated from anthropogenic aromatic hydrocarbons (ArHCs), such as benzene, toluene, xylenes, naphthalene and biphenyl

20 because HOM products from these ArHCs had compositions similar to OSs from the Arctic Centre Sea (Molteni et al., 2018). In Arctic pack ice zone, $18 \%$ of total OSs were derived from BVOC and 12\% from AVOC (AVOC/BVOC-derived OSs account for both sides). BVOC-derived OSs comprised 14\% and 19\% in the Antarctic Kunlun Station and Zhongshan Station, repectively, and AVOC-derived OSs accounted for $14 \%$ and $23 \%$. The percentages of BVOC-derived OSs from these three sites were similar and reflected the fact that the contribution of BVOCs did not make a difference at these three

25 sites and the formation of BVOC-derived OSs mainly depended on the reaction steps involving sulfur-containing ingredients. On the other hand, AVOC-derived OSs at the Zhongshan Station sites contained higher percentages than those from the other two sites. Considering human activities, one of the aerosol emission sources over Zhongshan Station was anthropogenic pollution and was attributed to the direct impact of developing research activities on the station and longdistance transporting air pollutants from Southern Hemisphere continents (Jianjun et al., 2010; Thamban and Thakur, 2013;

$30 \mathrm{Xu}$ et al., 2019). Kunlun Station is located about $7.3 \mathrm{~km}$ southwest to Dome A on the Antarctic plateau at an elevation of $4087 \mathrm{~m}$; the first Chinese Antarctic inland research station suffers from extremely low temperature, an extremely dry atmosphere and low wind speeds. Dome A is a barren field bereft of plants but the human activities from Kunlun research 
Atmos. Chem. Phys. Discuss., https://doi.org/10.5194/acp-2019-410

Manuscript under review for journal Atmos. Chem. Phys.

station. In addition, the back-trajectory result obtained with HYSPLIT analysis (Fig. S1) also provides insight into the impact of sea spray transport, coastal plants and anthropogenic emissions from other research stations.

The noticeable point, however, was a large number of OSs from heretofore unrecognized precursors which comprised more than $60 \%$ of total detected OSs at each site. These unexplained OSs emphasized additional laboratory studies should be carried out in order to thoroughly investigate the formation mechanism of OSs and the latent contributions of OSs to atmosphere in the polar area.

The number of detected OSs was directly proportional to the concentration of non-sea-salt-sulfate (nss- $\mathrm{SO}_{4}$ ) aerosols, underscoring the nonnegligible contribution of anthropogenic contamination. The exceptionally high concentration of nss$\mathrm{SO}_{4}$ aerosols at the Arctic Pack Ice site may be a consequence of ship emissions, since ship exhausts can increase nss- $\mathrm{SO}_{4}$ by

10 a factor of two (Zhan et al., 2014). In addition, the O/C values from the Arctic Pack Ice site were the smallest among the four polar sites and close to the Guangzhou sites, demonstrating more in-situ production of SOAs derived from ship emissions occurred at this sampling site. Those particles, as well as $\mathrm{NO}_{\mathrm{x}}, \mathrm{SO}_{\mathrm{x}}, \mathrm{O}_{3}$ and hydrocarbons (HCs) emitted from the ship cruise accelerated the reaction rate of OS formation due to reactant increases and acidification. Zhongshan Station is located along the Antarctic east coast near Prydz Bay 1 km west of an Adelie penguin colony (Xie et al., 2002). According to previous

15 studies, potential sources of atmospheric sulfur from these sites include marine biogenic emissions, dust from distant continents, aerosols from stratospheric reservoir, VOCs from penguin droppings and exhausts from this station which are equipped with power houses (Xie et al., 2002; Minikin et al., 1998; Bates et al., 1992; Legrand et al., 2017). This may help explain the higher concentration of nss- $\mathrm{SO}_{4}$ aerosols and more OSs molecules detected in the atmosphere of Zhongshan Station.

20 The effect of aerosol acidity on the formation of OSs has been investigated (Riva et al., 2016b; Iinuma et al., 2007; Surratt et al., 2007; Chan et al., 2011). Acid conditions significantly enhance OS yields via acid-catalysed ring-opening of epoxy organic intermediates, which facilitates addition of sulfate anion to carbocation. This reactive uptake chemistry of epoxides is a significant pathway to BVOC-derived OSs. Other mechanisms of OS formation are unaffected by acidity, such as the heterogeneous reaction of $\mathrm{SO}_{2}$ or the sulfate anion radical with unsaturated compounds and nucleophilic substitution

25 of organonitrate by sulfate. We calculated the $\mathrm{pH}$ of aerosols at all four polar sites using ISORROPIA II, a thermodynamic equilibrium model (Fountoukis and Nenes, 2007) (Table 2). At the Arctic Centre Sea and Antarctic Kunlun Station, atmospheric aerosols were neutral/slightly alkaline, while aerosols from the Arctic Pack Ice and Antarctic Zhongshan Station were slightly acidic (estimated). The extremely low pH of Arctic Pack Ice samples resulted from the influence of ship emissions, based on the high concentration of nss- $\mathrm{SO}_{4}$ aerosols. The $\mathrm{pH}$ estimation and OS formation mechanisms suggest

30 that acid-catalysed epoxy chemistry was the primary formation pathway in aerosols samples from Arctic Pack Ice and Antarctic Zhongshan Station. This is consistent with the previous discussion on participation of AVOC and BVOC in OS formation. BVOC-derived OSs at the two acid sampling sites (Arctic Pack Ice and Antarctic Zhongshan Station) were higher in both number and percentage than those in the neutral/slightly alkaline (Arctic Centre Sea and Antarctic Kunlun Station). The OSs of the neutral/slightly alkaline atmosphere were due to multiphase oxidation of unsaturated organic interactions 
Atmos. Chem. Phys. Discuss., https://doi.org/10.5194/acp-2019-410

Manuscript under review for journal Atmos. Chem. Phys.

Discussion started: 6 May 2019

(c) Author(s) 2019. CC BY 4.0 License.

(c) (i)

Atmospheric

Chemistry

and Physics

Discussions

with $\mathrm{SO}_{2}$ and sulfate anion radicals involving photooxidation with $\mathrm{OH} / \mathrm{O}_{2}$. In addition, small amounts of alkali added to bulk aerosols can accelerate the rate of OS formation by esterification of sulfuric acid with alcohols (Li and Jang, 2013).

$\mathrm{RH}$ is considered as a factor influencing OS formation; nevertheless, it can lead to inconclusive OS yields (Li and Jang, 2013; Riva et al., 2015; Riva et al., 2016c; Barbosa et al., 2017; Kwong et al., 2018). Higher RH conditions inhibit OS

5 formation in an acid-catalysed epoxy system; this is likely due to dilution from additional water particles resulting in a decrease in aerosol acidity (Riva et al., 2015; Riva et al., 2016a; Riva et al., 2016c). Meanwhile, some groups have found that higher RH values increased OS yields at neutral pHs (Barbosa, 2017, J. Li, 2013). In our study, Arctic sites are relatively moist $(\mathrm{RH}=90 \%)$ while Antarctic sites are relatively dry $(\mathrm{RH}=50-65 \%)$. The impact of $\mathrm{RH}$ on OS formation showed behaviour opposite to what we previously reported and expected. Between the two acidic sites, Arctic Pack Ice had higher

$10 \mathrm{RH}$ as well as more OS constituents. Between the two neutral/slightly alkaline sites, more OS constituents were detected at the Antarctic Kunlun Station with lower RH. As a consequence, the effect of RH was not large enough to generate a substantial difference in OS formation and it should be put into comprehensive consideration in the potential impact of VOCs and S/IVOCs concentrations, sulfate aerosols, atmospheric oxidants and their interactions with each other.

\section{Conclusions}

15 Atmospheric particulate matter collected during CHINARE 14/15 in Arctic and Antarctic regions (Arctic Centre Sea, Arctic Pack Ice, Antarctic Kunlun Station and Antarctic Zhongshan Station) and Guangzhou urban/rural sites were analysed using ultra-high-resolution mass spectrometry with negative ESI mode. Four groups of tentatively determined compounds in the study areas (OSs, ONs, NOSs and OxyCs) were present and posted different molecular characteristics. In the polar sites, 20-500 organic compounds were identified with masses from 90-800 Da and more than 2000 compounds were identified in

20 Guangzhou sites. The compositions of detected compounds were different between polar areas and the Guangzhou area. OSs/NOSs and ONs represented $\sim 30 \%$ and $30-40 \%$ of the total compounds detected at polar sites, respectively, while compounds at the Guangzhou site were approximately $20 \%$ OSs/NOSs and $\sim 50 \%$ ONs. These differences could be explained by elevated $\mathrm{NO}_{x}$ concentrations from vehicle exhausts and night-time oxidation of $\mathrm{NO}_{3}$ in Guangzhou. Comparing sites in the same polar area (Arctic or Antarctic), more molecules were detected at lower-latitude sites than higher-latitude

25 sites; this suggested influences from other continents as well as human activities on polar area aerosols. In terms of molecular weight distributions, more high-molecular-weight compounds were observed in the polar areas than in Guangzhou. Combining that with the observation that compounds detected in the polar area exhibited a higher oxidation state $\left(\mathrm{OSc}_{\text {polar }}=\right.$ $\left.(-0.25)-(+0.04), \mathrm{OSc}_{\mathrm{GZ}}=(-0.47)-(-0.17)\right)$, we inferred that HMW compounds emitted from other continents were inclined to be initially preserved, transported to remote polar areas, where they participated in further oxidation and photochemical

30 reactions. Additionally, polar sites and the urban Guangzhou site showed similar patterns of polycyclic aromatic OS/NOS molecules in similar oxidative states and differed from the rural Guangzhou site, suggesting polar areas were intensely affected by anthropogenic pollutants. 
Atmos. Chem. Phys. Discuss., https://doi.org/10.5194/acp-2019-410

Manuscript under review for journal Atmos. Chem. Phys.

Chemistry

Discussion started: 6 May 2019

(c) Author(s) 2019. CC BY 4.0 License.

To investigate OS/NOS formation in polar areas, we examined potential precursors of OSs/NOSs detected at polar sites by comparing our results with those already published, AVOC/BVOC-derived OSs/NOSs and the effects of the atmospheric environment including concentrations of nss- $\mathrm{SO}_{4}$ aerosols, $\mathrm{pH}$ and $\mathrm{RH}$. Of the total OSs observed in the Arctic Pack Ice zone, the Antarctic Kunlun Station and the Antarctic Zhongshan Station, 18\%, 14\% and 19\% were derived from BVOC while 12\%,

$514 \%$ and 23\% came from AVOC. The relatively high contribution of AVOC to OSs/NOSs in Antarctica was partly due to developing Antarctic research activities and air pollutants transported from Southern Hemisphere continents. Since the precursors and formation mechanisms of OSs have not been unambiguously determined, over $60 \%$ of total OSs/NOSs at each site were unrecognized by their precursors. Impacts from human activities were also inferred from the positive correlation of the nss-SO $\mathrm{S}_{4}$ concentration and the number of detected OSs/NOSs compounds. From the perspective of aerosol

10 acidity, $\mathrm{pH}$ values at the Arctic Centre Sea and Antarctic Kunlun Station were neutral/slightly alkaline, while Arctic Pack Ice and Antarctic Zhongshan Station were slightly acidic. The reactive uptake of epoxides involving acid-catalysed ring opening is a significant formation pathway for BVOC-derived OS/NOS molecules; this led to conclusion that the formation mechanism of OS aerosols at Arctic Pack Ice and Antarctic Zhongshan Station was dominant by epoxy chemistry. This supposition was in agreement with higher involvement of BVOC in the OSs/NOSs formation at these two sites. Different

15 relative humidity values at these sampling sites had no apparent impact on the OSs/NOSs yields in our study.

Data availability. All data needed to draw the conclusions are present in the main text and/or the Supplement. For additional data, please contact the corresponding author (zqxie@ustc.edu.cn).

20 Author contributions. Z.Q.X. conceived and supervised this study. Y.Q.Y. and M.Z.performed the measurement.Y.Q.Y., Z.Q.X. and X.M.Wang interpreted the data. Y.Q.Y. wrote the manuscript with input from Z.Q.X.

Competing interests. The authors declare that they have no conflict of interest.

25 Acknowledgments. This work was supported by the National Natural Foundation of China (416761733). We thank Pengzhen He and Tianming Ma for sampling the polar samples during the 6th China Arctic Research Expedition and the 31th China Antarctic Research Expedition. We thank China Arctic and Antarctic Administration for fieldwork support. We thank Hao Yin and Airong Feng for their help in instrumental advice. The authors acknowledge the NOAA Air Resources Laboratory (ARL) for making the HYSPLIT transport and dispersion model available on the Internet 30 (http://www.arl.noaa.gov/ready.html). 
Atmos. Chem. Phys. Discuss., https://doi.org/10.5194/acp-2019-410

Manuscript under review for journal Atmos. Chem. Phys.

Discussion started: 6 May 2019

(c) Author(s) 2019. CC BY 4.0 License.

\section{References}

ACIA: Impacts of a Warming Arctic:Arctic Climate Impact Assessment. ACIA Overview Report, Cambridge Univ. Press, New York, 2004.

Barbara Nozière, S. E., Tomas Alsberg, Sara Holmström: Radical - initiated formation of organosulfates and surfactants in atmospheric aerosols, Geophysical Research Letters, 37, 1-6, 10.1029/2009GL041683, 2010.

Barbosa, T. S., Riva, M., Chen, Y., da Silva, C. M., Ameida, J. C. S., Zhang, Z., Gold, A., Arbilla, G., Bauerfeldt, G. F., and Surratt, J. D.: Chemical characterization of organosulfates from the hydroxyl radical-initiated oxidation and ozonolysis of cis-3-hexen-1-ol, Atmospheric Environment, 162, 141-151, 10.1016/j.atmosenv.2017.04.026, 2017.

Bates, T. S., Lamb, B. K., Guenther, A., Dignon, J., and Stoiber, R. E.: Sulfur emissions to the atmosphere from natural sourees, Journal of Atmospheric Chemistry, 14, 315-337, 10.1007/BF00115242, 1992.

Blair, S. L., MacMillan, A. C., Drozd, G. T., Goldstein, A. H., Chu, R. K., Pasa-Tolic, L., Shaw, J. B., Tolic, N., Lin, P., Laskin, J., Laskin, A., and Nizkorodov, S. A.: Molecular Characterization of Organosulfur Compounds in Biodiesel and Diesel Fuel Secondary Organic Aerosol, Environmental Science \& Technology, 51, 119-127, 10.1021/acs.est.6b03304, 2017.

Brimblecombe, P.: Air composition and chemistry, Cambridge University Press, 1996.

15 Bromwich, D. H., Nicolas, J. P., Monaghan, A. J., Lazzara, M. A., Keller, L. M., Weidner, G. A., and Wilson, A. B.: Central West Antarctica among the most rapidly warming regions on Earth, Nature Geoscience, 6, 139-145, 10.1038/ngeo1671, 2012.

Chan, M. N., Surratt, J. D., Chan, A. W. H., Schilling, K., Offenberg, J. H., Lewandowski, M., Edney, E. O., Kleindienst, T. E., Jaoui, M., Edgerton, E. S., Tanner, R. L., Shaw, S. L., Zheng, M., Knipping, E. M., and Seinfeld, J. H.: Influence of aerosol acidity on the chemical composition of secondary organic aerosol from $\beta$-caryophyllene, Atmos. Chem. Phys, 11, 1735-1751, 10.5194/acp-11-17352011, 2011.

Chen, T., and Jang, M.: Secondary organic aerosol formation from photooxidation of a mixture of dimethyl sulfide and isoprene, Atmospheric Environment, 46, 271-278, 10.1016/j.atmosenv.2011.09.082, 2012.

Cohen, J. L., Furtado, J. C., Barlow, M. A., Alexeev, V. A., and Cherry, J. E.: Arctic warming, increasing snow cover and widespread boreal winter cooling, Environmental Research Letters, 7, 014007, 10.1088/1748-9326/7/1/014007, 2012.

25 Darer, A. I., Cole-Filipiak, N. C., O'Connor, A. E., and Elrod, M. J.: Formation and stability of atmospherically relevant isoprene-derived organosulfates and organonitrates, Environ Sci Technol, 45, 1895-1902, 10.1021/es103797z, 2011.

Elder, A., and Oberdörster, G.: Translocation and effects of ultrafine particles outside of the lung, Clinics in occupational and environmental medicine, 5, 785-796, 10.1016/j.coem.2006.07.003, 2006.

Fountoukis, C., and Nenes, A.: ISORROPIA II: a computationally efficient thermodynamic equilibrium model for $\mathrm{K}^{+}-\mathrm{Ca}^{2+}-\mathrm{Mg}^{2+}-\mathrm{NH}_{4}{ }^{+}-$ $\mathrm{Na}^{+}-\mathrm{SO}_{4}{ }^{2-}-\mathrm{NO}_{3}{ }^{-}-\mathrm{Cl}^{-}-\mathrm{H}_{2} \mathrm{O}$ aerosols, Atmos. Chem. Phys., 7, 4639-4659, 10.5194/acp-7-4639-2007, 2007.

Frossard, A. A., Shaw, P. M., Russell, L. M., Kroll, J. H., Canagaratna, M. R., Worsnop, D. R., Quinn, P. K., and Bates, T. S.: Springtime Arctic haze contributions of submicron organic particles from European and Asian combustion sources, Journal of Geophysical Research, 116, 10.1029/2010jd015178, 2011.

Fu, P., Kawamura, K., Chen, J., and Barrie, L. A.: Isoprene, Monoterpene, and Sesquiterpene Oxidation Products in the High Arctic Aerosols during Late Winter to Early Summer, Environmental Science \& Technology, 43, 4022-4028, 10.1021/es803669a, 2009.

Fu, P. Q., Kawamura, K., Chen, J., Charrière, B., and Sempéré, R.: Organic molecular composition of marine aerosols over the Arctic Ocean in summer: contributions of primary emission and secondary aerosol formation, Biogeosciences, 10, 653-667, 10.5194/bg-10653-2013, 2013.

Goldstein, A. H., and Galbally, I. E.: Known and Unexplored Organic Constituents in the Earth's Atmosphere, Environmental Science \& Technology, 41, 1514-1521, 10.1021/es072476p, 2007.

Hallquist, M., Wenger, J. C., Baltensperger, U., Rudich, Y., Simpson, D., Claeys, M., Dommen, J., Donahue, N. M., George, C., Goldstein, A. H., Hamilton, J. F., Herrmann, H., Hoffmann, T., Iinuma, Y., Jang, M., Jenkin, M. E., Jimenez, J. L., Kiendler-Scharr, A., Maenhaut, W., McFiggans, G., Mentel, T. F., Monod, A., Prévôt, A. S. H., Seinfeld, J. H., Surratt, J. D., Szmigielski, R., and Wildt, J.: The formation, properties and impact of secondary organic aerosol: current and emerging issues, Atmos. Chem. Phys., 9, 5155-5236, 10.5194/acp-9-5155-2009, 2009.

Hansen, A. M. K., Kristensen, K., Nguyen, Q. T., Zare, A., Cozzi, F., Nøjgaard, J. K., Skov, H., Brandt, J., Christensen, J. H., Ström, J., Tunved, P., Krejci, R., and Glasius, M.: Organosulfates and organic acids in Arctic aerosols: speciation, annual variation and concentration levels, Atmos. Chem. Phys., 14, 7807-7823, 10.5194/acp-14-7807-2014, 2014.

Hawkins, L. N., Russell, L. M., Covert, D. S., Quinn, P. K., and Bates, T. S.: Carboxylic acids, sulfates, and organosulfates in processed continental organic aerosol over the southeast Pacific Ocean during VOCALS-REx 2008, Journal of Geophysical Research: Atmospheres, 115, 10.1029/2009JD013276, 2010.

Hettiyadura, A. P. S., Xu, L., Jayarathne, T., Skog, K., Guo, H., Weber, R. J., Nenes, A., Keutsch, F. N., Ng, N. L., and Stone, E. A.: Source apportionment of organic carbon in Centreville, AL using organosulfates in organic tracer-based positive matrix factorization, Atmospheric Environment, 186, 74-88, 10.1016/j.atmosenv.2018.05.007, 2018.

55 Hoffmann, T., Huang, R. J., and Kalberer, M.: Atmospheric analytical chemistry, Anal Chem, 83, 4649-4664, 10.1021/ac2010718, 2011. 
Atmos. Chem. Phys. Discuss., https://doi.org/10.5194/acp-2019-410

Manuscript under review for journal Atmos. Chem. Phys.

Discussion started: 6 May 2019

(c) Author(s) 2019. CC BY 4.0 License.

Atmospheric

Chemistry

and Physics

Discussions

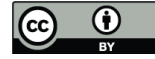

Hu, Q. H., Xie, Z. Q., Wang, X. M., Kang, H., He, Q. F., and Zhang, P.: Secondary organic aerosols over oceans via oxidation of isoprene and monoterpenes from Arctic to Antarctic, Sci Rep, 3, 2280, 10.1038/srep02280, 2013.

Iinuma, Y., Müller, C., Berndt, T., Böge, O., Claeys, M., and Herrmann, H.: Evidence for the Existence of Organosulfates from $\beta$-Pinene Ozonolysis in Ambient Secondary Organic Aerosol, Environmental Science \& Technology, 41, 6678-6683, 10.1021/es070938t, 2007.

5 Iinuma, Y., Böge, O., Kahnt, A., and Herrmann, H.: Laboratory chamber studies on the formation of organosulfates from reactive uptake of monoterpene oxides, Physical Chemistry Chemical Physics, 11, 7985-7997, 10.1039/B904025K, 2009.

IPCC: Climate Change 2013: the physical science basis. Contribution of working group I to the fifth assessment report of the intergovernmental panel on climate change., 2013.

Jacobson, M. C., Hansson, H. C., Noone, K. J., and Charlson, R. J.: Organic atmospheric aerosols: Review and state of the science, Reviews of Geophysics, 38, 267-294, 10.1029/1998RG000045, 2000.

Jacobson, M. Z.: Isolating nitrated and aromatic aerosols and nitrated aromatic gases as sources of ultraviolet light absorption, Journal of Geophysical Research: Atmospheres, 104, 3527-3542, 10.1029/1998JD100054, 1999.

Jianjun, W., Liqi, C., Xulin, Y., and Yuanhui, Z.: Characteristics of metals in the aerosols of Zhongshan Station, Antarctica, Chinese Journal of Polar Science, 21, 5, 10.3724/SP.J.1085.2010.00046, 2010.

15 Jimenez, J. L., Canagaratna, M. R., Donahue, N. M., Prevot, A. S. H., Zhang, Q., Kroll, J. H., DeCarlo, P. F., Allan, J. D., Coe, H., Ng, N. L., Aiken, A. C., Docherty, K. S., Ulbrich, I. M., Grieshop, A. P., Robinson, A. L., Duplissy, J., Smith, J. D., Wilson, K. R., Lanz, V. A., Hueglin, C., Sun, Y. L., Tian, J., Laaksonen, A., Raatikainen, T., Rautiainen, J., Vaattovaara, P., Ehn, M., Kulmala, M., Tomlinson, J. M., Collins, D. R., Cubison, M. J., Dunlea, J., Huffman, J. A., Onasch, T. B., Alfarra, M. R., Williams, P. I., Bower, K., Kondo, Y., Schneider, J., Drewnick, F., Borrmann, S., Weimer, S., Demerjian, K., Salcedo, D., Cottrell, L., Griffin, R., Takami, A., Miyoshi, T., Hatakeyama, S., Shimono, A., Sun, J. Y., Zhang, Y. M., Dzepina, K., Kimmel, J. R., Sueper, D., Jayne, J. T., Herndon, S. C., Trimborn, A. M., Williams, L. R., Wood, E. C., Middlebrook, A. M., Kolb, C. E., Baltensperger, U., and Worsnop, D. R.: Evolution of Organic Aerosols in the Atmosphere, Science, 326, 1525, 10.1126/science.1180353, 2009.

Kawamura, K., Seméré, R., Imai, Y., Fujii, Y., and Hayashi, M.: Water soluble dicarboxylic acids and related compounds in Antarctic aerosols, Journal of Geophysical Research: Atmospheres, 101, 18721-18728, 10.1029/96JD01541, 1996.

25 Kim, S., Kramer, R. W., and Hatcher, P. G.: Graphical Method for Analysis of Ultrahigh-Resolution Broadband Mass Spectra of Natural Organic Matter, the Van Krevelen Diagram, Analytical Chemistry, 75, 5336-5344, 10.1021/ac034415p, 2003.

Kroll, J. H., and Seinfeld, J. H.: Chemistry of secondary organic aerosol: Formation and evolution of low-volatility organics in the atmosphere, Atmospheric Environment, 42, 3593-3624, https://doi.org/10.1016/j.atmosenv.2008.01.003, 2008.

Kroll, J. H., Donahue, N. M., Jimenez, J. L., Kessler, S. H., Canagaratna, M. R., Wilson, K. R., Altieri, K. E., Mazzoleni, L. R., Wozniak, A. S., Bluhm, H., Mysak, E. R., Smith, J. D., Kolb, C. E., and Worsnop, D. R.: Carbon oxidation state as a metric for describing the chemistry of atmospheric organic aerosol, Nature Chemistry, 3, 133, 10.1038/nchem.948, 2011.

Kuang, B. Y., Lin, P., Hu, M., and Yu, J. Z.: Aerosol size distribution characteristics of organosulfates in the Pearl River Delta region, China, Atmospheric Environment, 130, 23-35, 10.1016/j.atmosenv.2015.09.024, 2016.

Kwong, K. C., Chim, M. M., Davies, J. F., Wilson, K. R., and Chan, M. N.: Importance of sulfate radical anion formation and chemistry in heterogeneous $\mathrm{OH}$ oxidation of sodium methyl sulfate, the smallest organosulfate, Atmospheric Chemistry and Physics, 18, 2809-2820, 10.5194/acp-18-2809-2018, 2018.

Laskin, A., Laskin, J., and Nizkorodov, S. A.: Chemistry of Atmospheric Brown Carbon, Chemical Reviews, 115, 4335-4382, 10.1021/cr5006167, 2015.

Legrand, M., Wolff, E., and Wagenbach, D.: Antarctic aerosol and snowfall chemistry: implications for deep Antarctic ice-core chemistry, Annals of Glaciology, 29, 66-72, 10.3189/172756499781821094, 2017.

Li, J., and Jang, M.: Kinetic study of esterification of sulfuric acid with alcohols in aerosol bulk phase, Atmos. Chem. Phys. Discuss., 2013, 23217-23250, 10.5194/acpd-13-23217-2013, 2013.

Liggio, J., and Li, S.-M.: Organosulfate formation during the uptake of pinonaldehyde on acidic sulfate aerosols, Geophysical Research Letters, 33, 10.1029/2006GL026079, 2006.

45 Lin, P., Rincon, A. G., Kalberer, M., and Yu, J. Z.: Elemental Composition of HULIS in the Pearl River Delta Region, China: Results Inferred from Positive and Negative Electrospray High Resolution Mass Spectrometric Data, Environmental Science \& Technology, 46, 7454-7462, 10.1021/es300285d, 2012a.

Lin, P., Yu, J. Z., Engling, G., and Kalberer, M.: Organosulfates in Humic-like Substance Fraction Isolated from Aerosols at Seven Locations in East Asia: A Study by Ultra-High-Resolution Mass Spectrometry, Environmental Science \& Technology, 46, 13118-13127, $10.1021 / \mathrm{es} 303570 \mathrm{v}, 2012 \mathrm{~b}$.

Lin, Y.-H., Zhang, H., Pye, H. O. T., Zhang, Z., Marth, W. J., Park, S., Arashiro, M., Cui, T., Budisulistiorini, S. H., Sexton, K. G., Vizuete, W., Xie, Y., Luecken, D. J., Piletic, I. R., Edney, E. O., Bartolotti, L. J., Gold, A., and Surratt, J. D.: Epoxide as a precursor to secondary organic aerosol formation from isoprene photooxidation in the presence of nitrogen oxides, Proceedings of the National Academy of Sciences, 110, 6718, 10.1073/pnas.1221150110, 2013.

55 Lu, J. W., Flores, J. M., Lavi, A., Abo-Riziq, A., and Rudich, Y.: Changes in the optical properties of benzo[a]pyrene-coated aerosols upon heterogeneous reactions with NO2 and NO3, Physical chemistry chemical physics : PCCP, 13, 6484-6492, 10.1039/c0cp02114h, 2011. 
Atmos. Chem. Phys. Discuss., https://doi.org/10.5194/acp-2019-410

Manuscript under review for journal Atmos. Chem. Phys.

Discussion started: 6 May 2019

(c) Author(s) 2019. CC BY 4.0 License.

Atmospheric

Chemistry

and Physics

Discussions

Lukács, H., Gelencsér, A., Hoffer, A., Kiss, G., Horváth, K., and Hartyáni, Z.: Quantitative assessment of organosulfates in sizesegregated rural fine aerosol, Atmos. Chem. Phys., 9, 231-238, 10.5194/acp-9-231-2009, 2009.

Ma, Y., Xu, X., Song, W., Geng, F., and Wang, L.: Seasonal and diurnal variations of particulate organosulfates in urban Shanghai, China, Atmospheric Environment, 85, 152-160, https://doi.org/10.1016/j.atmosenv.2013.12.017, 2014.

5 Mael, L. E., Jacobs, M. I., and Elrod, M. J.: Organosulfate and Nitrate Formation and Reactivity from Epoxides Derived from 2-Methyl-3buten-2-ol, The Journal of Physical Chemistry A, 119, 4464-4472, 10.1021/jp510033s, 2015.

Mazzera, D. M., Lowenthal, D. H., Chow, J. C., and Watson, J. G.: Sources of PM10 and sulfate aerosol at McMurdo station, Antarctica, Chemosphere, 45, 347-356, https://doi.org/10.1016/S0045-6535(00)00591-9, 2001.

McNeill, V. F., Woo, J. L., Kim, D. D., Schwier, A. N., Wannell, N. J., Sumner, A. J., and Barakat, J. M.: Aqueous-phase secondary organic aerosol and organosulfate formation in atmospheric aerosols: a modeling study, Environ Sci Technol, 46, 8075-8081, 10.1021/es3002986, 2012.

Meade, L. E., Riva, M., Blomberg, M. Z., Brock, A. K., Qualters, E. M., Siejack, R. A., Ramakrishnan, K., Surratt, J. D., and Kautzman, K. E.: Seasonal variations of fine particulate organosulfates derived from biogenic and anthropogenic hydrocarbons in the mid-Atlantic United States, Atmospheric Environment, 145, 405-414, 10.1016/j.atmosenv.2016.09.028, 2016.

15 Minikin, A., Legrand, M., Hall, J., Wagenbach, D., Kleefeld, C., Wolff, E., Pasteur, E. C., and Ducroz, F.: Sulfur-containing species (sulfate and methanesulfonate) in coastal Antarctic aerosol and precipitation, Journal of Geophysical Research: Atmospheres, 103, 10975-10990, 10.1029/98JD00249, 1998.

Mishra, V. K., Kim, K.-H., Hong, S., and Lee, K.: Aerosol composition and its sources at the King Sejong Station, Antarctic peninsula, Atmospheric Environment, 38, 4069-4084, 10.1016/j.atmosenv.2004.03.052, 2004.

20 Mitchell, J.: Visual range in the polar regions with particular reference to the Alaskan Arctic, J. Atmos. Terr. Phys, 17, 195-211, 1957.

Mochida, M., Kitamori, Y., Kawamura, K., Nojiri, Y., and Suzuki, K.: Fatty acids in the marine atmosphere: Factors governing their concentrations and evaluation of organic films on sea-salt particles, Journal of Geophysical Research: Atmospheres, 107, AAC 1-1AAC 1-10, 10.1029/2001JD001278, 2002.

Molteni, U., Bianchi, F., Klein, F., El Haddad, I., Frege, C., Rossi, M. J., Dommen, J., and Baltensperger, U.: Formation of highly oxygenated organic molecules from aromatic compounds, Atmospheric Chemistry and Physics, 18, 1909-1921, 10.5194/acp-18-19092018, 2018.

N. L. Ng, A. J. K., J. D. Surratt, A. W. H. Chan, P. S. Chhabra, A. Sorooshian, H. O. T. Pye, J. D. Crounse, P. O. Wennberg, R. C. Flagan, J. H. Seinfeld: Secondary organic aerosol (SOA) formation from reaction of isoprene with nitrate radicals (NO3), Atmos. Chem. Phys, 8 , 4117-4140, 2008.

30 Nguyen, Q. T., Glasius, M., Sørensen, L. L., Jensen, B., Skov, H., Birmili, W., Wiedensohler, A., Kristensson, A., Nøjgaard, J. K., and Massling, A.: Seasonal variation of atmospheric particle number concentrations, new particle formation and atmospheric oxidation capacity at the high Arctic site Villum Research Station, Station Nord, Atmos. Chem. Phys., 16, 11319-11336, 10.5194/acp-16-113192016, 2016.

Novakov, T., and Penner, J. E.: Large contribution of organic aerosols to cloud-condensation-nuclei concentrations, Nature, 365, 823-826, 10.1038/365823a0, 1993.

Nozière, B., Ekström, S., Alsberg, T., and Holmström, S.: Radical-initiated formation of organosulfates and surfactants in atmospheric aerosols, Geophysical Research Letters, 37, 10.1029/2009GL041683, 2010.

Nozière, B., Kalberer, M., Claeys, M., Allan, J., D’Anna, B., Decesari, S., Finessi, E., Glasius, M., Grgić, I., Hamilton, J. F., Hoffmann, T., Iinuma, Y., Jaoui, M., Kahnt, A., Kampf, C. J., Kourtchev, I., Maenhaut, W., Marsden, N., Saarikoski, S., Schnelle-Kreis, J., Surratt, J. D., Szidat, S., Szmigielski, R., and Wisthaler, A.: The Molecular Identification of Organic Compounds in the Atmosphere: State of the Art and Challenges, Chemical Reviews, 115, 3919-3983, 10.1021/cr5003485, 2015.

Olson, C. N., Galloway, M. M., Yu, G., Hedman, C. J., Lockett, M. R., Yoon, T., Stone, E. A., Smith, L. M., and Keutsch, F. N.: Hydroxycarboxylic Acid-Derived Organosulfates: Synthesis, Stability, and Quantification in Ambient Aerosol, Environmental Science \& Technology, 45, 6468-6474, 10.1021/es201039p, 2011.

45 Pang, Y., Turpin, B. J., and Gundel, L. A.: On the Importance of Organic Oxygen for Understanding Organic Aerosol Particles, Aerosol Science and Technology, 40, 128-133, 10.1080/02786820500423790, 2006.

Passananti, M., Kong, L., Shang, J., Dupart, Y., Perrier, S., Chen, J., Donaldson, D. J., and George, C.: Organosulfate Formation through the Heterogeneous Reaction of Sulfur Dioxide with Unsaturated Fatty Acids and Long-Chain Alkenes, Angewandte Chemie International Edition, 55, 10336-10339, 10.1002/anie.201605266, 2016.

50 Perri, M. J., Lim, Y. B., Seitzinger, S. P., and Turpin, B. J.: Organosulfates from glycolaldehyde in aqueous aerosols and clouds: Laboratory studies, Atmospheric Environment, 44, 2658-2664, 10.1016/j.atmosenv.2010.03.031, 2010.

Pope Iii, C. A., Burnett, R. T., Thun, M. J., Calle, E. E., Krewski, D., Ito, K., and Thurston, G. D.: Lung Cancer, Cardiopulmonary Mortality, and Long-term Exposure to Fine Particulate Air Pollution, JAMA, 287, 1132-1141, 10.1001/jama.287.9.1132, 2002.

Quinn, P. K., Shaw, G., Andrews, E., Dutton, E. G., Ruoho-Airola, T., and Gong, S. L.: Arctic haze: current trends and knowledge gaps, Tellus B: Chemical and Physical Meteorology, 59, 99-114, 10.1111/j.1600-0889.2006.00236.x, 2007. 
Atmos. Chem. Phys. Discuss., https://doi.org/10.5194/acp-2019-410

Manuscript under review for journal Atmos. Chem. Phys.

Discussion started: 6 May 2019

(c) Author(s) 2019. CC BY 4.0 License.

Atmospheric

Chemistry

and Physics

Discussions

\section{(c) (7)}

Ravishankara, A. R.: Heterogeneous and Multiphase Chemistry in the Troposphere, Science, 276, 1058, 10.1126/science.276.5315.1058, 1997.

Riva, M., Tomaz, S., Cui, T., Lin, Y.-H., Perraudin, E., Gold, A., Stone, E. A., Villenave, E., and Surratt, J. D.: Evidence for an Unrecognized Secondary Anthropogenic Source of Organosulfates and Sulfonates: Gas-Phase Oxidation of Polycyclic Aromatic Hydrocarbons in the Presence of Sulfate Aerosol, Environmental Science \& Technology, 49, 6654-6664, 10.1021/acs.est.5b00836, 2015.

Riva, M., Budisulistiorini, S. H., Zhang, Z., Gold, A., and Surratt, J. D.: Chemical characterization of secondary organic aerosol constituents from isoprene ozonolysis in the presence of acidic aerosol, Atmospheric Environment, 130, 5-13, 10.1016/j.atmosenv.2015.06.027, 2016a.

Riva, M., Da Silva Barbosa, T., Lin, Y. H., Stone, E. A., Gold, A., and Surratt, J. D.: Chemical characterization of organosulfates in secondary organic aerosol derived from the photooxidation of alkanes, Atmos. Chem. Phys., 16, 11001-11018, 10.5194/acp-16-110012016, 2016b.

Riva, M., Da Silva Barbosa, T., Lin, Y. H., Stone, E. A., Gold, A., and Surratt, J. D.: Characterization of Organosulfates in Secondary Organic Aerosol Derived from the Photooxidation of Long-Chain Alkanes, Atmospheric Chemistry and Physics Discussions, 1-39, 10.5194/acp-2016-20, 2016c.

15 Russell, L. M., Hawkins, L. N., Frossard, A. A., Quinn, P. K., and Bates, T. S.: Carbohydrate-like composition of submicron atmospheric particles and their production from ocean bubble bursting, Proceedings of the National Academy of Sciences, 107, 6652, 10.1073/pnas.0908905107, 2010.

Schindelka, J., Iinuma, Y., Hoffmann, D., and Herrmann, H.: Sulfate radical-initiated formation of isoprene-derived organosulfates in atmospheric aerosols, Faraday Discussions, 165, 237-259, 10.1039/C3FD00042G, 2013.

20 Seinfeld, J. H., Pandis, S. N., and Noone, K.: Atmospheric chemistry and physics: from air pollution to climate change, Physics Today, 51, 88, 10.1063/1.882420, 1998.

Seppälä, A., Verronen, P. T., Clilverd, M. A., Randall, C. E., Tamminen, J., Sofieva, V., Backman, L., and Kyrölä, E.: Arctic and Antarctic polar winter NOx and energetic particle precipitation in 2002-2006, Geophysical Research Letters, 34, 10.1029/2007GL029733, 2007.

25 Shalamzari, M. S., Kahnt, A., Vermeylen, R., Kleindienst, T. E., Lewandowski, M., Cuyckens, F., Maenhaut, W., and Claeys, M.: Characterization of Polar Organosulfates in Secondary Organic Aerosol from the Green Leaf Volatile 3-Z-Hexenal, Environmental Science \& Technology, 48, 12671-12678, 10.1021/es503226b, 2014.

Shalamzari, M. S., Vermeylen, R., Blockhuys, F., Kleindienst, T. E., Lewandowski, M., Szmigielski, R., Rudzinski, K. J., Spólnik, G., Danikiewicz, W., Maenhaut, W., and Claeys, M.: Characterization of polar organosulfates in secondary organic aerosol from the unsaturated aldehydes 2-E-pentenal, 2-E-hexenal, and 3-Z-hexenal, Atmos. Chem. Phys., 16, 7135-7148, 10.5194/acp-16-7135-2016, 2016.

Shang, J., Passananti, M., Dupart, Y., Ciuraru, R., Tinel, L., Rossignol, S., Perrier, S., Zhu, T., and George, C.: SO2 Uptake on Oleic Acid: A New Formation Pathway of Organosulfur Compounds in the Atmosphere, Environmental Science \& Technology Letters, 3, 67-72, 10.1021/acs.estlett.6b00006, 2016.

35 Shao, M., Zhang, Y., Zeng, L., Tang, X., Zhang, J., Zhong, L., and Wang, B.: Ground-level ozone in the Pearl River Delta and the roles of VOC and NOx in its production, Journal of Environmental Management, 90, 512-518, https://doi.org/10.1016/j.jenvman.2007.12.008, 2009.

Song, C., Gyawali, M., Zaveri, R. A., Shilling, J. E., and Arnott, W. P.: Light absorption by secondary organic aerosol from $\alpha$-pinene: Effects of oxidants, seed aerosol acidity, and relative humidity, Journal of Geophysical Research: Atmospheres, 118, 11,741-711,749, 10.1002/jgrd.50767, 2013.

Staudt, S., Kundu, S., Lehmler, H. J., He, X., Cui, T., Lin, Y. H., Kristensen, K., Glasius, M., Zhang, X., Weber, R. J., Surratt, J. D., and Stone, E. A.: Aromatic organosulfates in atmospheric aerosols: synthesis, characterization, and abundance, Atmos Environ (1994), 94, 366-373, 10.1016/j.atmosenv.2014.05.049, 2014.

Stone, E. A., Yang, L., Yu, L. E., and Rupakheti, M.: Characterization of organosulfates in atmospheric aerosols at Four Asian locations, Atmospheric Environment, 47, 323-329, 10.1016/j.atmosenv.2011.10.058, 2012.

Surratt, J. D., Kroll, J. H., Kleindienst, T. E., Edney, E. O., Claeys, M., Sorooshian, A., Ng, N. L., Offenberg, J. H., Lewandowski, M., Jaoui, M., Flagan, R. C., and Seinfeld, J. H.: Evidence for Organosulfates in Secondary Organic Aerosol, Environmental Science \& Technology, 41, 517-527, 10.1021/es062081q, 2007.

Surratt, J. D., Gómez-González, Y., Chan, A. W. H., Vermeylen, R., Shahgholi, M., Kleindienst, T. E., Edney, E. O., Offenberg, J. H., Lewandowski, M., Jaoui, M., Maenhaut, W., Claeys, M., Flagan, R. C., and Seinfeld, J. H.: Organosulfate Formation in Biogenic Secondary Organic Aerosol, The Journal of Physical Chemistry A, 112, 8345-8378, 10.1021/jp802310p, 2008.

Szmigielski, R.: Evidence for C 5 organosulfur secondary organic aerosol components from in-cloud processing of isoprene: Role of reactive SO 4 and SO 3 radicals, Atmospheric Environment, 130, 14-22, 10.1016/j.atmosenv.2015.10.072, 2016.

Tao, S., Lu, X., Levac, N., Bateman, A. P., Nguyen, T. B., Bones, D. L., Nizkorodov, S. A., Laskin, J., Laskin, A., and Yang, X.: Molecular Characterization of Organosulfates in Organic Aerosols from Shanghai and Los Angeles Urban Areas by Nanospray- 
Atmos. Chem. Phys. Discuss., https://doi.org/10.5194/acp-2019-410

Manuscript under review for journal Atmos. Chem. Phys.

Discussion started: 6 May 2019

(c) Author(s) 2019. CC BY 4.0 License.

Atmospheric

Chemistry

and Physics

Discussions

Desorption Electrospray Ionization High-Resolution Mass Spectrometry, Environmental Science \& Technology, 48, 10993-11001, 10.1021/es5024674, 2014.

Thamban, M., and Thakur, R. C.: Trace metal concentrations of surface snow from Ingrid Christensen Coast, East Antarctica-spatial variability and possible anthropogenic contributions, Environmental Monitoring and Assessment, 185, 2961-2975, 10.1007/s10661-0122764-0, 2013.

Tolocka, M. P., and Turpin, B.: Contribution of Organosulfur Compounds to Organic Aerosol Mass, Environmental Science \& Technology, 46, 7978-7983, 10.1021/es300651v, 2012.

Tong, H., Kourtchev, I., Pant, P., Keyte, I. J., O'Connor, I. P., Wenger, J. C., Pope, F. D., Harrison, R. M., and Kalberer, M.: Molecular composition of organic aerosols at urban background and road tunnel sites using ultra-high resolution mass spectrometry, Faraday Discussions, 189, 51-68, 10.1039/C5FD00206K, 2016.

Tunved, P., Ström, J., and Krejci, R.: Arctic aerosol life cycle: linking aerosol size distributions observed between 2000 and 2010 with air mass transport and precipitation at Zeppelin station, Ny-Ålesund, Svalbard, Atmos. Chem. Phys., 13, 3643-3660, 10.5194/acp-13-36432013, 2013.

Wang, X., Hayeck, N., Brüggemann, M., Yao, L., Chen, H., Zhang, C., Emmelin, C., Chen, J., George, C., and Wang, L.: Chemical Characteristics of Organic Aerosols in Shanghai: A Study by Ultrahigh-Performance Liquid Chromatography Coupled With Orbitrap Mass Spectrometry, Journal of Geophysical Research: Atmospheres, 112, 11,703-711,722, 10.1002/2017JD026930, $2017 \mathrm{a}$.

Wang, X. K., Rossignol, S., Ma, Y., Yao, L., Wang, M. Y., Chen, J. M., George, C., and Wang, L.: Molecular characterization of atmospheric particulate organosulfates in three megacities at the middle and lower reaches of the Yangtze River, Atmos Chmistry and Physics, 16, 2285-2298, 10.5194/acp-16-2285-2016, 2016.

20 Wang, Y., Hu, M., Lin, P., Guo, Q., Wu, Z., Li, M., Zeng, L., Song, Y., Zeng, L., Wu, Y., Guo, S., Huang, X., and He, L.: Molecular Characterization of Nitrogen-Containing Organic Compounds in Humic-like Substances Emitted from Straw Residue Burning, Environ Sci Technol, 51, 5951-5961, 10.1021/acs.est.7b00248, 2017b.

Wu, Z., Rodgers, R. P., and Marshall, A. G.: Two- and Three-Dimensional van Krevelen Diagrams: A Graphical Analysis Complementary to the Kendrick Mass Plot for Sorting Elemental Compositions of Complex Organic Mixtures Based on UltrahighResolution Broadband Fourier Transform Ion Cyclotron Resonance Mass Measurements, Analytical Chemistry, 76, 2511-2516, 10.1021/ac0355449, 2004.

Xie, Z.-Q., Sun, L.-G., Wang, J.-J., and Liu, B.-Z.: A potential source of atmospheric sulfur from penguin colony emissions, Journal of Geophysical Research: Atmospheres, 107, ACH 5-1-ACH 5-10, 10.1029/2002JD002114, 2002.

Xu, G., Chen, L., Zhang, M., Zhang, Y., Wang, J., and Lin, Q.: Year-round records of bulk aerosol composition over the Zhongshan Station, Coastal East Antarctica, Air Quality, Atmosphere \& Health, 12, 271-288, 10.1007/s11869-018-0642-9, 2019.

Yassine, M. M., Harir, M., Dabek-Zlotorzynska, E., and Schmitt-Kopplin, P.: Structural characterization of organic aerosol using Fourier transform ion cyclotron resonance mass spectrometry: aromaticity equivalent approach, Rapid Commun Mass Spectrom, 28, 2445-2454, 10.1002/rcm.7038, 2014.

Zhan, J., Gao, Y., Li, W., Chen, L., Lin, H., and Lin, Q.: Effects of ship emissions on summertime aerosols at Ny-Alesund in the Arctic, Atmospheric Pollution Research, 5, 500-510, https://doi.org/10.5094/APR.2014.059, 2014.

Zhang, H., and Worton, D. R.: Organosulfates as Tracers for Secondary Organic Aerosol (SOA) Formation from 2- Methyl-3-Buten-2-ol (MBO) in the Atmosphere, Environmental Science \& Technology, 46, 9437-9446, 10.1021/es301648z, 2012. 
Atmos. Chem. Phys. Discuss., https://doi.org/10.5194/acp-2019-410

Manuscript under review for journal Atmos. Chem. Phys.

Atmospheric

Chemistry

Discussion started: 6 May 2019

(c) Author(s) 2019. CC BY 4.0 License.

and Physics

Discussions

(c)

Table 1. Summary of tentatively assigned formulas of atmospheric particles observed in the six aerosol sampling sites.

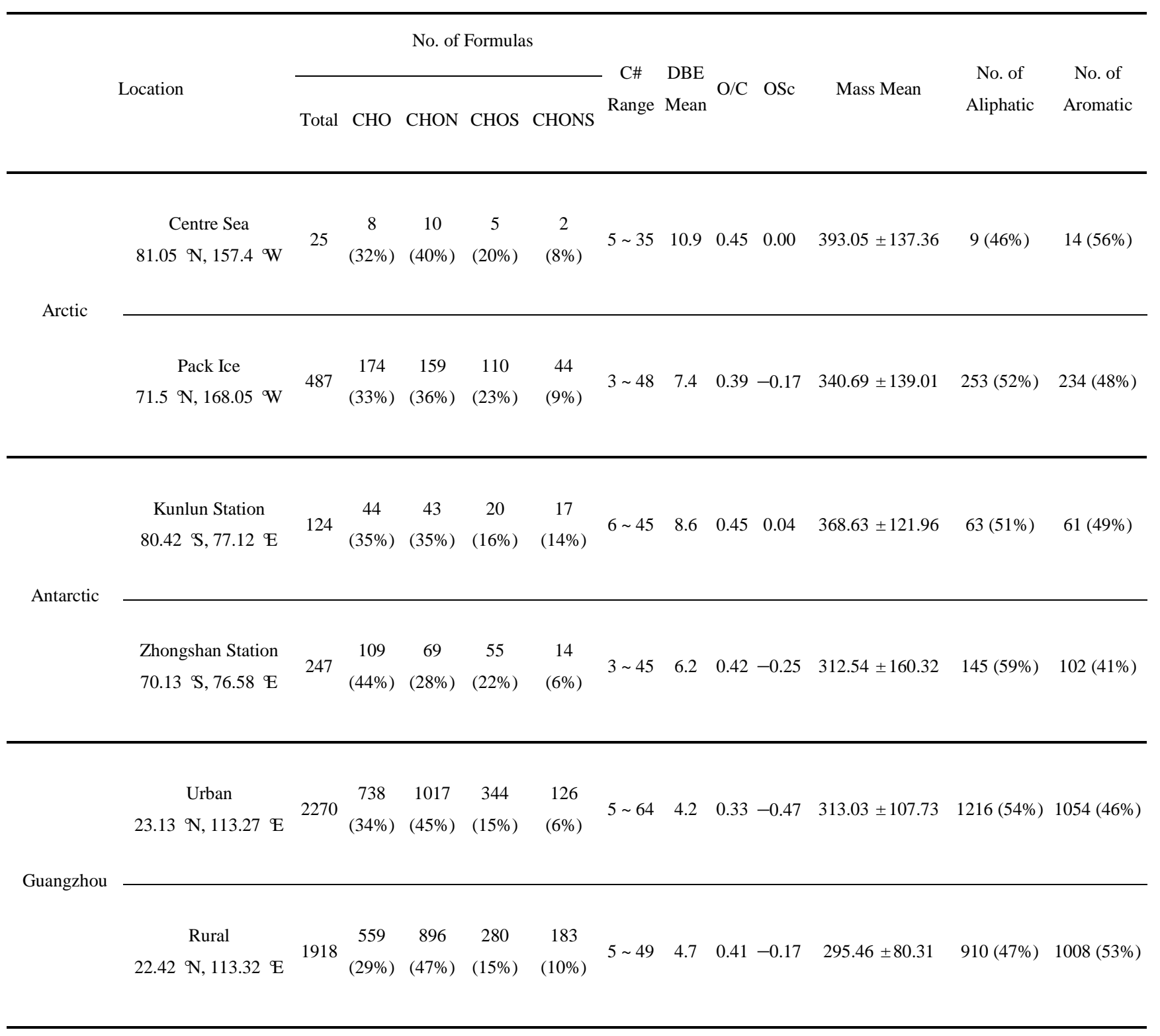


Atmos. Chem. Phys. Discuss., https://doi.org/10.5194/acp-2019-410

Manuscript under review for journal Atmos. Chem. Phys.

Atmospheric

Chemistry

Discussion started: 6 May 2019

(c) Author(s) 2019. CC BY 4.0 License.

$\frac{\text { and Physics }}{\text { Discussions }}$

(c) (i)

Table 2. The concentrations of inorganic aerosols, $\mathrm{RH}$, temperature and calculated $\mathrm{pH}$ in polar sampling sites.

$\begin{array}{llllllllllll} & \mathrm{Na}^{+} & \mathrm{K}^{+} & \mathrm{Mg}^{2+} & \mathrm{Ca}^{2+} & \mathrm{NH}_{4}^{+} & \mathrm{SO}_{4}{ }^{2-} & \mathrm{NO}_{3}^{-} & \mathrm{Cl}^{-} & \mathrm{RH}^{-} & \mathrm{Temp} & \mathrm{pH} \\ \text { Sampling Sites } & \left(\mu \mathrm{g} / \mathrm{m}^{3}\right) & \left(\mu \mathrm{g} / \mathrm{m}^{3}\right) & \left(\mu \mathrm{g} / \mathrm{m}^{3}\right) & \left(\mu \mathrm{g} / \mathrm{m}^{3}\right) & \left(\mu \mathrm{g} / \mathrm{m}^{3}\right) & \left(\mu \mathrm{g} / \mathrm{m}^{3}\right) & \left(\mu \mathrm{g} / \mathrm{m}^{3}\right) & \left(\mu \mathrm{g} / \mathrm{m}^{3}\right) & (\%) & (\mathrm{K}) & \end{array}$

\begin{tabular}{|c|c|c|c|c|c|c|c|c|c|c|c|c|}
\hline \multirow{2}{*}{ Arctic } & Centre Sea & 0.3426 & - & 0.0485 & 0.0275 & 0.1487 & 0.2360 & 0.0160 & 0.0287 & 90 & 275.15 & 7.7 \\
\hline & Pack Ice & 0.6834 & 0.1212 & 0.0690 & 0.0200 & 0.1697 & 2.0452 & 0.1356 & 0.2643 & 90 & 260.05 & 3.8 \\
\hline \multirow{2}{*}{ Antarctic } & $\begin{array}{l}\text { Kunlun } \\
\text { Station }\end{array}$ & 0.4776 & 0.1140 & 0.0195 & 0.0473 & - & 0.4041 & 0.0641 & 0.1849 & 65 & 246.98 & 7.8 \\
\hline & $\begin{array}{l}\text { Zhongshan } \\
\text { Station }\end{array}$ & 0.1058 & 0.1244 & 0.0537 & 0.0729 & - & 0.3066 & 0.0583 & 0.1576 & 50 & 266.10 & 4.8 \\
\hline
\end{tabular}


Atmos. Chem. Phys. Discuss., https://doi.org/10.5194/acp-2019-410

Manuscript under review for journal Atmos. Chem. Phys.

Discussion started: 6 May 2019

(c) Author(s) 2019. CC BY 4.0 License.
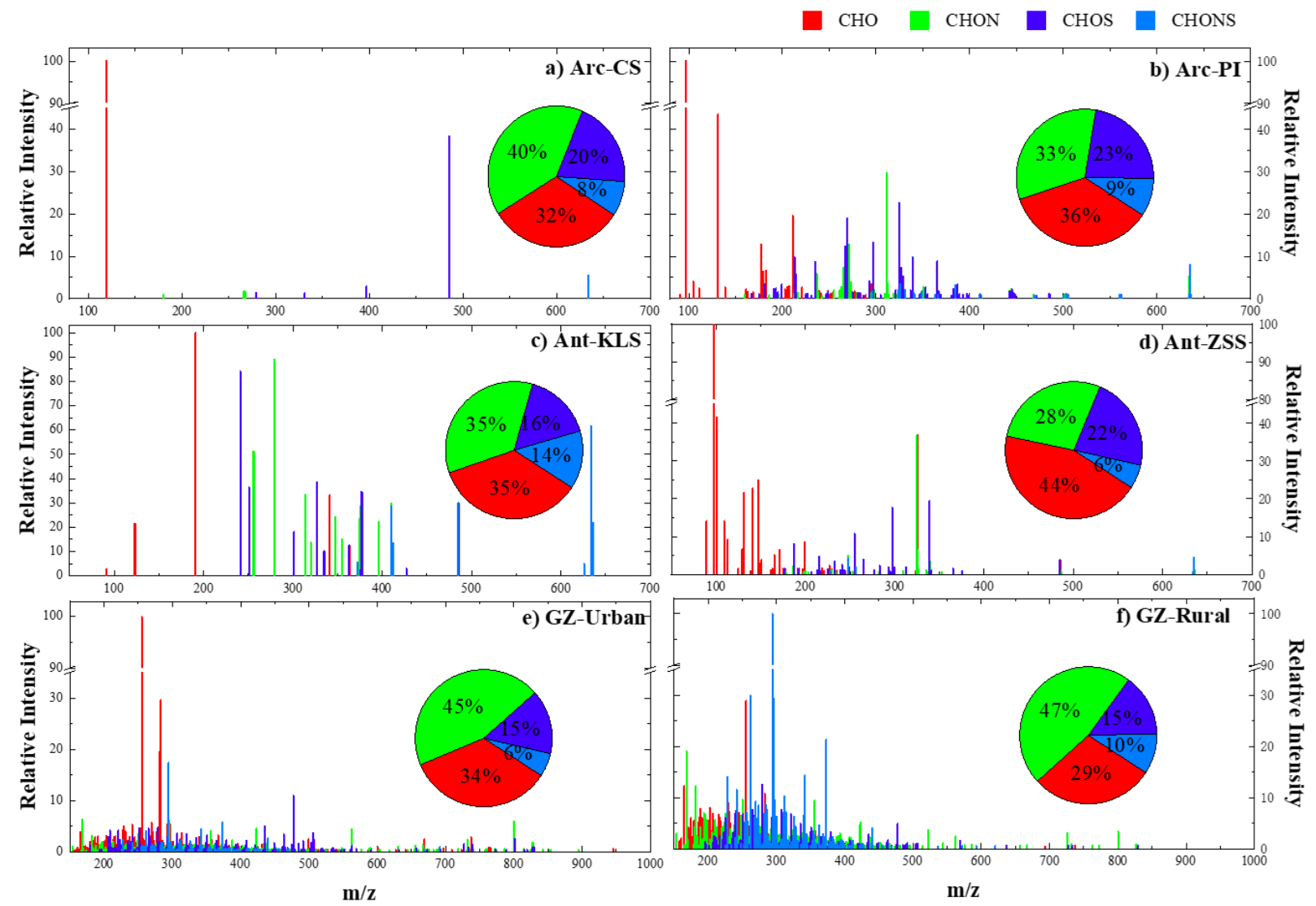

Figure 1. Mass spectra of detected compounds (CHO, CHON, CHOS, CHONS) reconstructed from Orbitrap MS analysis in the negative ionization mode. $X$ axis corresponds to the $\mathbf{m} / \mathbf{z}$ of the assigned species and $Y$ axis corresponds to the relative intensity of each molecular. Note that the most abundant peak (CHO, CHON, CHOS and CHONS) was set as 100\%. The pie charts showed the percentage of each subgroup were taken up in the total number of detected compounds. a) Arc-CS, Arctic Centre Sea Zone; b) Arc-PI, Arctic Pack Ice Zone; c) Ant-KLS, Antarctic Kunlun Station; d) Ant-ZSS, Antarctic Zhongshan Station; e) GZ-Urban, Guangzhou Urban Sampling Site (Environment Monitoring Station); f) GZ-Rural, Guangzhou Rural Sampling Site (Wangqinsha). 
Atmos. Chem. Phys. Discuss., https://doi.org/10.5194/acp-2019-410

Manuscript under review for journal Atmos. Chem. Phys.

Discussion started: 6 May 2019

(c) Author(s) 2019. CC BY 4.0 License.
Atmospheric

Chemistry

and Physics

Discussions

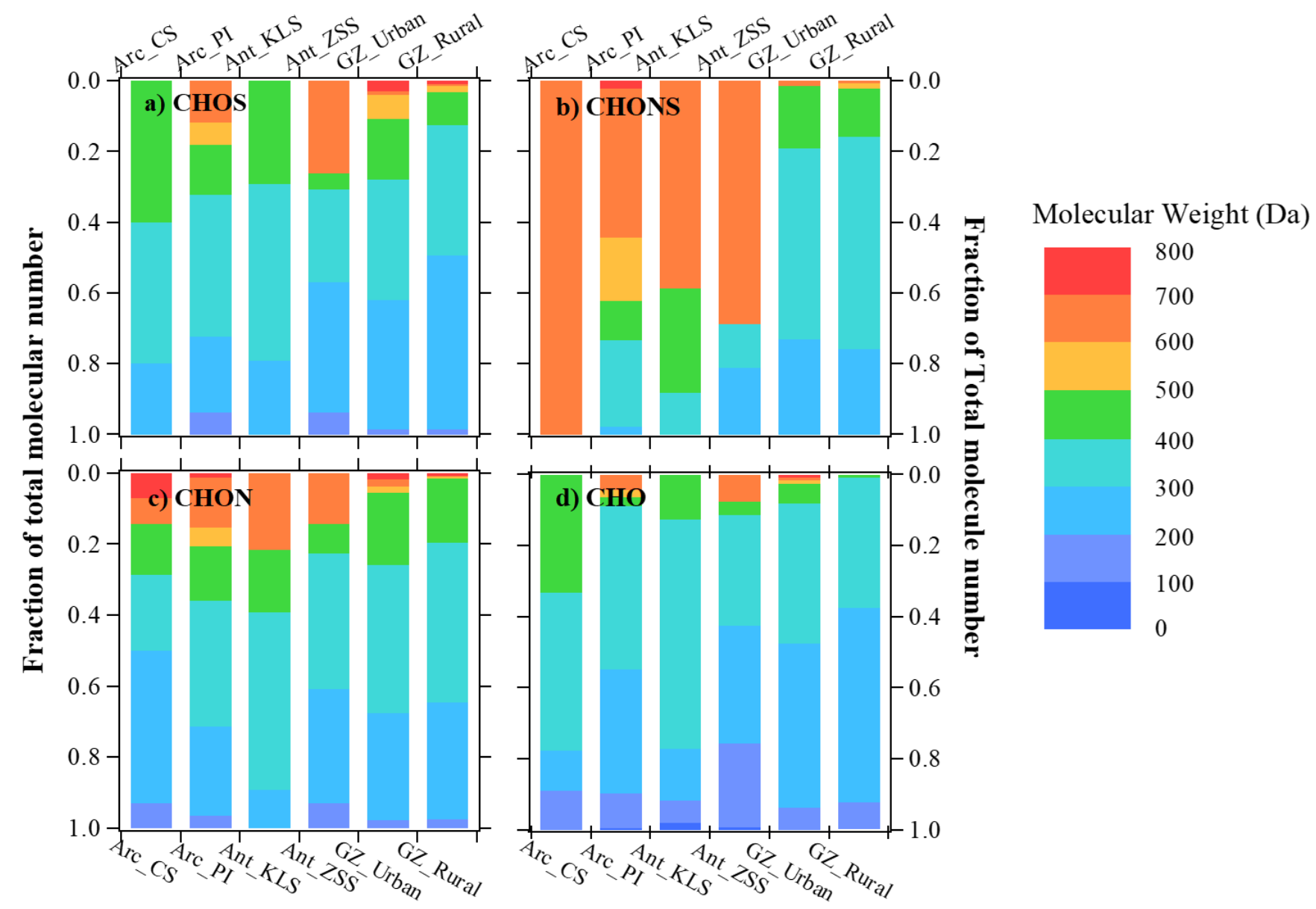

Figure 2. The distributions of detected CHOS (a), CHONS (b), CHON (c) and CHO (d) molecules in the molecular weight range in the six sampling sites. The color-coding indicates the molecular weights range from 0 Da to $800 \mathrm{Da}$. 
Atmos. Chem. Phys. Discuss., https://doi.org/10.5194/acp-2019-410

Manuscript under review for journal Atmos. Chem. Phys.

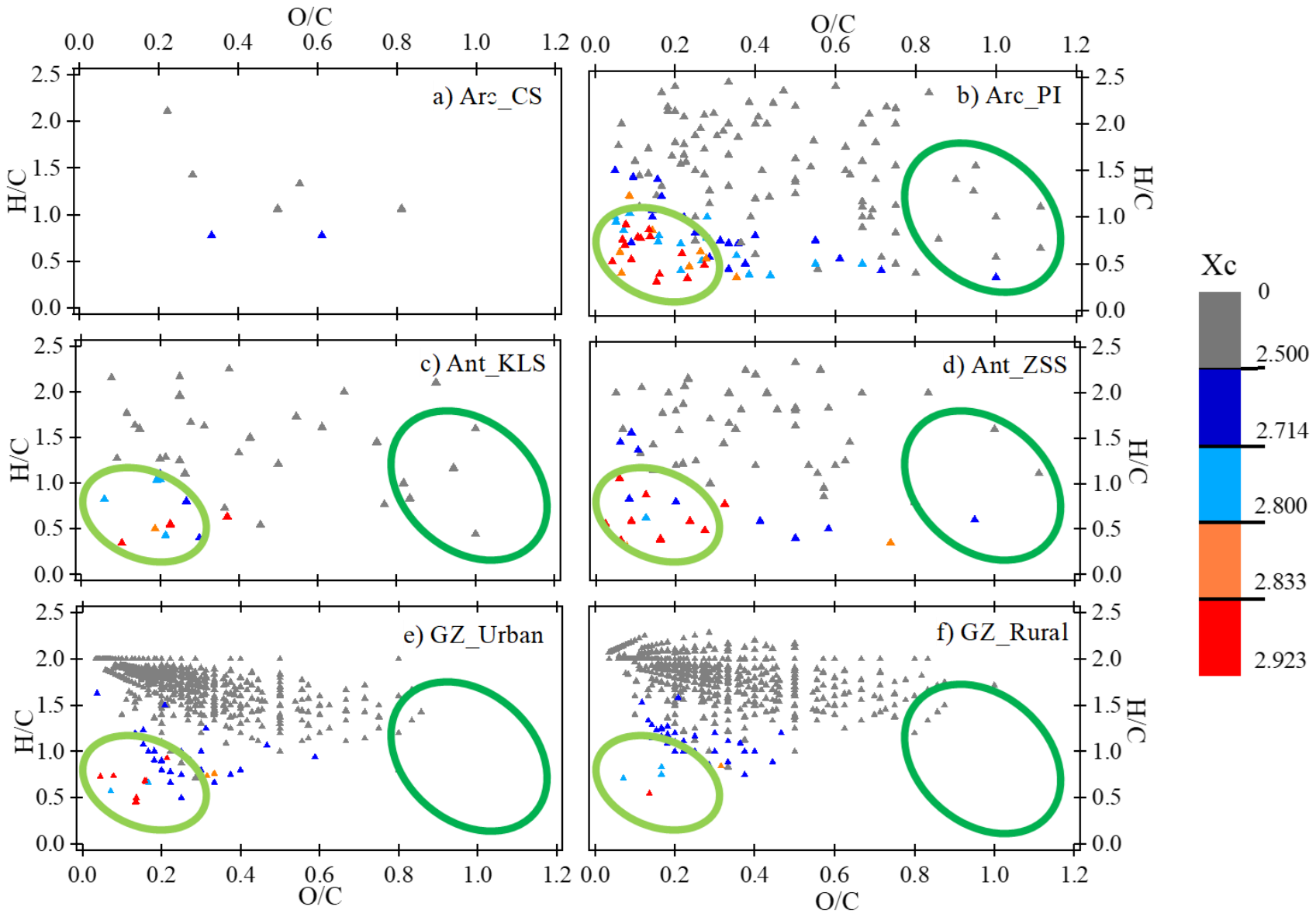

Figure 3. Van Krevelen Diagrams for OSs and NOSs molecules in the six sampling sites. The color-coding indicates the Xc values calculated from Eq. (2). The gray marks represent aliphatic compounds (Xc < 2.500); the dark blue marks represent aromatics with a benzene core structure $(2.500 \leq X c<2.714)$; the light blue marks represent aromatics with a naphthalene core structure $(2.714 \leq \mathrm{Xc}<2.800)$; the orange marks represent aromatics with a anthracene core structure $(2.800 \leq \mathrm{Xc}<2.833)$; the red marks represent aromatics with a pyrene core structure $(2.833 \leq \mathrm{Xc}<2.923)$. 
Atmos. Chem. Phys. Discuss., https://doi.org/10.5194/acp-2019-410

Manuscript under review for journal Atmos. Chem. Phys.

Discussion started: 6 May 2019

(C) Author(s) 2019. CC BY 4.0 License.
Atmospheric

Chemistry

and Physics

Discussions

(c) $\underset{\mathrm{BY}}{(-)}$
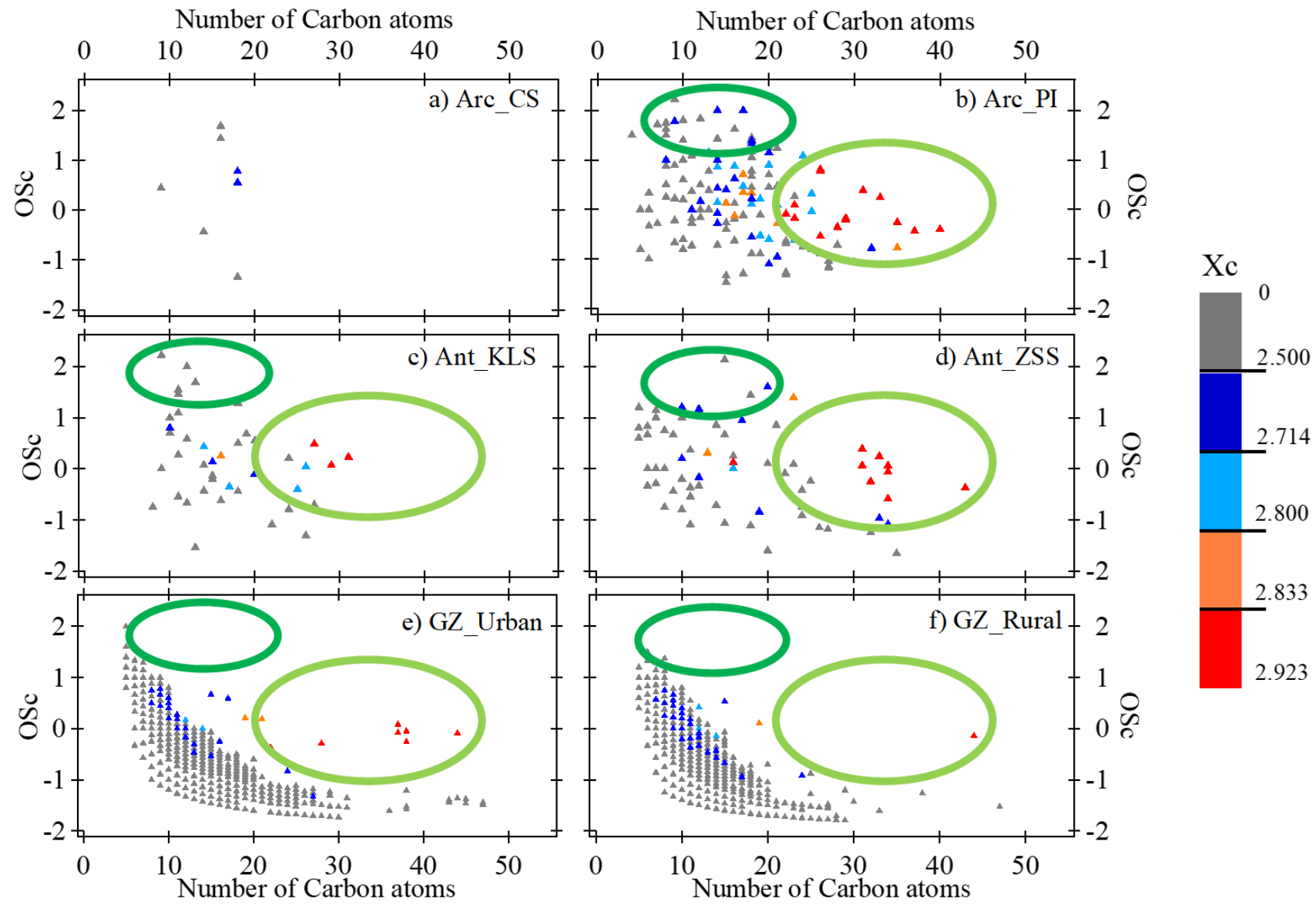

Figure 4. Carbon Oxidation State (OSc) plots for OSs and NOSs molecules in the six sampling sites. The color-coding indicates the Xc values calculated from Eq. (2). The gray marks represent aliphatic compounds $(\mathrm{Xc}<2.500)$; the dark blue marks represent aromatics with a benzene core structure $(2.500 \leq X c<2.714)$; the light blue marks represent aromatics with a naphthalene core structure $(2.714 \leq \mathrm{Xc}<2.800)$; the orange marks represent aromatics with a anthracene core structure $(2.800 \leq \mathrm{Xc}<2.833)$; the red marks represent aromatics with a pyrene core structure $(2.833 \leq \mathrm{Xc}<2.923)$. 
Atmos. Chem. Phys. Discuss., https://doi.org/10.5194/acp-2019-410

Manuscript under review for journal Atmos. Chem. Phys.

Discussion started: 6 May 2019

(C) Author(s) 2019. CC BY 4.0 License.
Atmospheric

Chemistry

and Physics

Discussions

(c) (i)

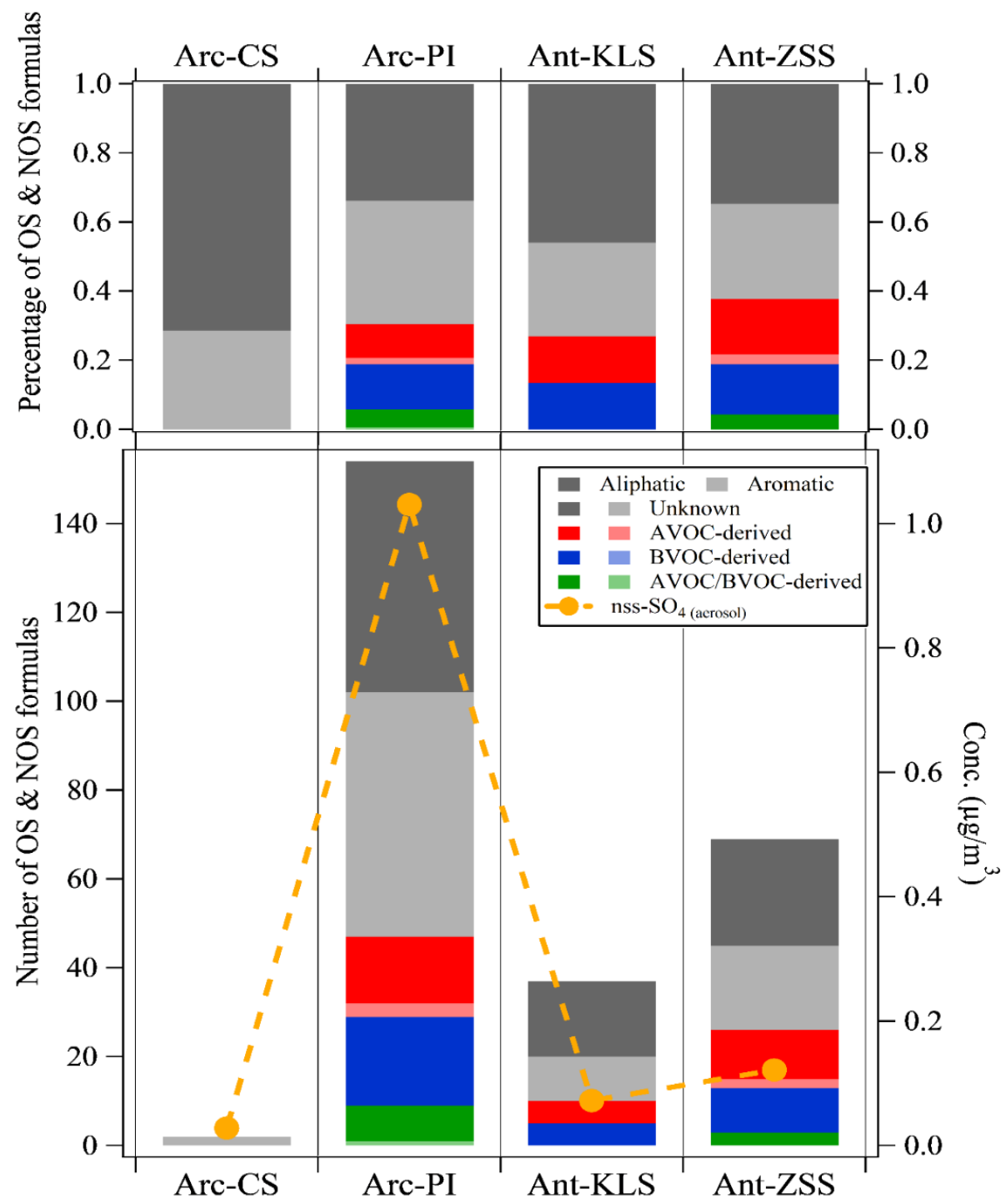

Figure 5. The potential precursor distributions of detected OSs and NOSs in Arctic Center Sea, Arctic Pack Ice, Antarctic Kunlun Station and Antarctic Zhongshan Station sampling sites. The dark color and light color indicate aliphatics and aromatics, relatively. The red, blue, green and grey color represent OSs derived from anthropogenic VOCs, biogenic VOCs, both of the two kinds of VOCs and unidentified precursors. The orange circle indicates the concentrations of nss-SO4 aerosols in the four polar sampling sites. 